\title{
LA EFICACIA TRANSFRONTERIZA DE LOS ACUERDOS DE MEDIACIÓN Y LA CONVENCIÓN DE SINGAPUR: ¿GRANDES ESPERANZAS?
}

\section{THE CROSS-BORDER EFFECTIVENESS OF MEDIATED SETTLEMENTS AND THE SINGAPORE CONVENTION: GREAT EXPECTATIONS?}

\author{
BÁRBARA SÁNCHEZ LÓPEZ** \\ Profesora Contratada Doctora interina \\ Universidad Complutense \\ ORCID ID: 0000-0002-8530-1907
}

Recibido: 23.06.2020 / Aceptado: 01.07.2020

DOI: https://doi.org/10.20318/cdt.2020.5677

\begin{abstract}
Resumen: En el presente trabajo se exponen, desde la perspectiva procesal europea y española, los problemas que plantea el régimen armonizado de reconocimiento y ejecución de acuerdos obtenidos en mediación que propone la Convención de Singapur de 2019. La atribución automática de eficacia ejecutiva que esta Convención anuda al mero documento privado del acuerdo obtenido con la asistencia de un mediador con tal que conste por escrito, firmado por las partes, con el fin de resolver una controversia comercial internacional, pone en jaque el sistema de garantías con el que muchos Estados de la familia de civil law, tras un largo proceso histórico, hemos revestido el acceso a la actividad ejecutiva estatal.
\end{abstract}

Palabras clave: Mediación internacional. Reconocimiento y ejecución. Resolución de controversias. Convención de Singapur de Mediación. Títulos ejecutivos.

Abstract: This paper presents, with European and Spanish procedural perspectives, the problems posed by the harmonized framework for recognition and enforcement of settlement agreements proposed by the 2019 Singapore Convention. The automatic enforceability attached to the mere private document of mediated settlement that it is in writing, signed by the parties, resolving an international commercial dispute, calls into question the system of guarantees that after a long historical process has been established in many countries in the family of civil law to allow access to State enforcement proceedings.

Keywords: International mediated settlements. Mediation. Recognition and Enforcement. Commercial dispute resolution. Singapore Convention on Mediation, Enforceable instruments.

Sumario: I. El debut de la Convención de Singapur de Mediación.- 1. La entrada en vigor de la Convención de Singapur y el impasse europeo.- 2. El indispensable impulso de un marco uniforme de ejecución de acuerdos de mediación transnacionales.- II. ¿Dónde estamos en materia

\footnotetext{
*Este trabajo fue preparado para ser defendido en el Seminario «Hacia un proceso civil convergente con Europa: balance de situación», dirigido por los Profs. Fernando Gascón Inchausti y Pilar Peiteado Mariscal, que debería haberse celebrado en la Facultad de Derecho de la UCM el 25 de junio de 2020 y que tuvo que ser suspendido como consecuencia del estado de alarma declarado en España en virtud del Real Decreto 463/2020, de 14 de marzo, con ocasión de la situación de emergencia sanitaria provocada por el coronavirus SARS-COV-2. Es uno de los resultados del proyecto de investigación "Hacia un proceso civil convergente con Europa. Hitos presentes y retos futuros" (PGC2018-094693-B-I00), financiado por el Ministerio de Ciencia e Innovación.

**basanche@ucm.es
} 
de eficacia extraterritorial de los acuerdos de mediación? 1. El reconocimiento y la ejecución de la mediación en la Directiva 2008/52/CE. A) De la falta de eficacia ejecutiva de los acuerdos de mediación y su aseguramiento mediante homologación por autoridades nacionales. B) Los avances en materia de reconocimiento y ejecución de decisiones y acuerdos de otros instrumentos europeos: a) El reconocimiento y la ejecución de resoluciones judiciales en materia civil en el marco del RB I bis; b) La circulación del título ejecutivo europeo de créditos no impugnados; c) El reconocimiento y la ejecución en materia de responsabilidad parental y sustracción de menores.- 2. La tendencia europea hacia la facilitación de la ejecutividad de decisiones en materia civil sobre la base de títulos y documentos de eficacia ejecutiva en el Estado UE de origen: una cuestión de garantías.- 3. De los silencios y de otras omisiones de la Directiva 2008/52/CE de Mediación- 4. El caso italiano ¿como ejemplo nacional? de impulso a la mediación.- III. ¿La hora de la armonización internacional del régimen de reconocimiento y ejecución de los acuerdos de mediación transfronterizos? 1. El arranque de los trabajos de la CNUDMI.- 2. El ámbito de aplicación de la CSM. A) El acuerdo escrito firmado por las partes obtenido en mediación con el fin de resolver una controversia comercial internacional. a) Acuerdo obtenido en mediación; b) Exigencia de la forma escrita y de la firma del acuerdo. Idioma y traducción; c) Carácter internacional y comercial del acuerdo obtenido. La «deslocalización» del acuerdo; B) Materias excluidas de la CSM.- IV. ¿En qué consiste la «eficacia extraterritorial» que atribuye la Convención? 1. La «which-is-no-called-“recognition"» del acuerdo obtenido en mediación.- 2. La eficacia ejecutiva del acuerdo obtenido en mediación comercial transnacional: el «título ejecutivo» de la CSM. A) La solicitud de medidas ejecutivas; B) Los problemas de equivalencia del «título» de la Convención; C) El ámbito de cognición en el seno del proceso de ejecución español.- 3. Los motivos de denegación del art. 5 CSM. A) Causas de denegación que fundan el control de oficio por el tribunal; B) Causas de oposición alegables a instancia de parte.- 4. Las «reclamaciones paralelas» en el marco de la CSM.- 5. Epílogo.

\section{El debut de la convención de singapur de mediación}

\section{La entrada en vigor de la Convención de Singapur y el impasse europeo}

1. El día 12 de septiembre de 2020 es una fecha señalada en el calendario jurídico internacional: este sábado entra en vigor la Convención de las Naciones Unidas sobre los Acuerdos de Transacción Internacionales Resultantes de la Mediación, aprobada mediante Resolución de la Asamblea General de 20 de diciembre de 2018, que recibe el nombre abreviado de «Convención de Singapur sobre la Mediación» (en adelante, la CSM) ${ }^{1}$.

2. La entrada en vigor de este instrumento, de acuerdo con su art. 14, se ha producido al cabo de seis meses desde el depósito del tercer instrumento de ratificación, correspondiente -tras la iniciativa de Singapur y de Fiji- a Qatar. Al tiempo en que se escriben estas líneas solo Arabia Saudí (en mayo de 2020), Bielorusia (en el mes de julio) y Ecuador (el día 9 de septiembre de 2020), han completado la ratificación de la CSM, de entre los más de cuarenta Estados que estamparon su firma en la Convención celebrada en Singapur el día 7 de agosto de 2019; incluidas, entre otros muchos países, potencias económicas como EE.UU., la República Popular China e India.

3. Cabe señalar que ni la Unión Europea (UE), ni sus Estados miembros, han firmado la CSM. $\mathrm{Su}$ firma y ratificación se encuentran, al parecer, en fase de estudio, aunque por parte del representante estadounidense que participó en la negociación de la CSM, Tімотну SCHNABel, sabemos que la UE ha sido siempre escéptica sobre la necesidad de promover una acción armonizada en este campo ${ }^{2}$. Y no es

\footnotetext{
${ }^{1}$ Documentos Oficiales de la Asamblea General, Septuagésimo tercer periodo de sesiones (A/RES/73/198). El texto y la situación de firma y ratificación de esta Convención puede consultarse en el sitio https://www.singaporeconvention.org/, que está dedicado a ella (fecha de consulta de este y de todos los enlaces de este trabajo: 15.06.2020).

2 Vid. T. Schnabel, "The Singapore Convention on Mediation: A Framework for the Cross-Border Recognition and Enforcement of Mediated Settlements", en Pepperdine Dispute Resolution Law Journal 1(2019), pp. 5-6, v.e. disponible en https:// digitalcommons.pepperdine.edu/drlj/vol19/iss1/1.
} 
de extrañar que así sea, si se consideran las garantías de la mediación transnacional en el ámbito UE que se expondrán más adelante y de las que la Convención, simplemente, prescinde.

4. Por lo demás, debe recordarse la competencia exclusiva que, sobre la base de los arts. $67.1 \mathrm{y}$ 4 y 81 TFUE, detenta la UE -y no los Estados miembros- para firmar y ratificar acuerdos con terceros Estados en materia que afecte o altere la normativa unieuropea, así como el fenómeno de progresiva ampliación de esta competencia exclusiva a medida en que la UE ha expandido el radio de acción de su propio sistema de Derecho internacional privado ${ }^{3}$. En la materia que ocupa a la CSM, no es baladí que la competencia de la UE se extienda a garantizar en el espacio judicial civil europeo, literalmente ex art. art. 81.2 TFUE, los siguientes objetivos: «a) el reconocimiento mutuo, entre los Estados miembros, de las resoluciones judiciales y extrajudiciales, así como su ejecución»; «e) una tutela judicial efectiva»; «f) la eliminación de los obstáculos al buen funcionamiento de los procedimientos civiles, fomentando si es necesario la compatibilidad de las normas de procedimiento civil aplicables en los Estados miembros»; y «g) el desarrollo de métodos alternativos de resolución de litigios».

5. Con la materia relativa al arbitraje privado internacional - como es sabido- no se han presentado problemas porque la UE ha inhibido su actividad legislativa para dejar que sigan actuando los numerosos convenios internacionales que están consolidados; en especial, el de reconocimiento y ejecución de Nueva York de 10 de junio de 1958. Pero en materia de mediación, la UE ha llevado la delantera frente a la iniciativa de la Comisión de Naciones Unidas para el Derecho Mercantil Internacional (CNUDMI) y ahora el marco unieuropeo condiciona la firma y ratificación de la CSM. De hecho, la negociación de la CSM por parte de la UE se ha desarrollado con base en un mandato a la Comisión Europea, como autoridad concernida ex art. 6.2 de la Directiva 2008752/CE, sobre la base de una posición coordinada con los Estados miembros que no prejuzga las eventuales competencias de estos en la posterior adhesión.

6. Por su parte, la CSM ha dejado la cuestión abierta mediante la previsión de que participen en la Convención «organizaciones regionales de integración económica» que, estando constituidas por Estados soberanos, tengan «competencia sobre algunos asuntos que se rijan por la presente convención» (art. 12), en cuyo caso deben especificarse y notificar cualquier cambio que se produzca en el elenco de asuntos. Además, también está previsto que, cuando sea pertinente en razón del número de Estados miembros, «la organización regional de integración económico no contará como Parte además de los Estados miembros de dicha organización que sean Partes en la Convención» (art. 12.1.i.f.).

7. Pues bien, en el momento en que nos encontramos, el rumbo del comercio internacional post covid determinará, a la postre, el éxito de este instrumento y, con el tiempo, podremos ponderar si las virtudes que se están asociando a este texto son exageradas o no. Por el momento, hay que señalar como muy ambiciosa $-\mathrm{y}$ tal vez, prematura - la pretensión de este tratado multilateral que aspira a ser a la mediación lo que el Convenio de Nueva York de 1958 es al arbitraje: un régimen armonizado internacional que facilita la libre circulación - en los países que lo han ratificado- y la inmediata efectividad de los acuerdos comerciales transnacionales obtenidos con la asistencia de carácter no dirimente de un tercero, cualquiera que sea la denominación que se les atribuya: mediación, conciliación, «transacción resultante de mediación», etc ${ }^{4}$. El tiempo dirá si la CSM funciona como palanca para impulsar el recur-

${ }^{3}$ Vid., sobre este particular, A. L. Calvo Caravaca, A. L., y J. Carrascosa González, Derecho internacional Privado, vol. I, $16^{\text {a }}$ ed., Granada, 2016, pp. 121-122.

${ }^{4} \mathrm{La}$ CSM - pero no los instrumentos unieuropeos- aluden a la transacción y a la mediación como términos correlativos, pese a que en muchos ordenamientos transacción, mediación y conciliación son figuras conceptualmente autónomas y jurídicamente diferenciadas. La propia CSM porta en su título la mención a los «Acuerdos de Transacción Internacionales resultantes de la Mediación», pese a que, como ha apuntado Esplugues MотA, con toda razón, se trata de una denominación «inexacta y equívoca, en cuanto combina dos nociones jurídicamente independientes y no necesariamente interrelacionadas, como son transacción y mediación» (C. Esplugues Mota, "La Convención de Singapur de 2018 sobre mediación y la creación de un título deslocalizado dotado de fuerza ejecutiva: una apuesta novedosa, y un mal relato", en Revista Española de Derecho Internacional, vol. 72-1, enero-junio 2020, p. 56, nota 20, http://dx.doi.org/10.17103/redi.72.1.2020.1.02). Aunque la cuestión no es 
so a la mediación en las controversias comerciales transfronterizas como lo hizo en su momento, en un contexto económico más propicio, la Convención de Nueva York con el arbitraje.

\section{El indispensable impulso de un marco uniforme de ejecución de acuerdos de mediación trans- nacionales}

8. Durante los últimos treinta años hemos asistido a una proliferación de iniciativas desde instancias legislativas de todo orden -locales, autonómicas, nacionales, europeas e internaciones-, dirigidas a alentar procedimientos para alcanzar soluciones pactadas por los interesados que descongestionen el aparato jurisdiccional estatal, conocidas genéricamente con el nombre de Alternative Dispute Resolution (ADR) o Métodos Alternativos de Resolución de Conflictos (MARC); y, en particular, se está fomentando la mediación como instrumento que permita cuajar una llamada «cultura de la mediación y la resolución amistosa de conflictos» ${ }^{5}$.

9. Por lo general, el fomento de la mediación ha alumbrado leyes que la disciplinan y establecen sus principios reguladores, dentro de un marco de amplios márgenes de flexibilidad y de libertad procedimentales, con ciertos estándares de confidencialidad y de profesionalización del mediador, la salvaguarda del orden público como límite a la autonomía de la voluntad, y con facilitación de efectos - directa o indirectamente- ejecutivos al acuerdo resultante de la pacificación de la controversia.

10. Ahora ha llegado el turno de remover los obstáculos a la libre circulación de estos acuerdos en el plano internacional mediante un régimen convencional multilateral de reconocimiento y ejecución de los acuerdos comerciales transnacionales obtenidos en mediación ${ }^{6}$.

11. Han hecho falta muy pocos años para advertir que el vacío normativo de un régimen homogéneo de reconocimiento y ejecución en materia comercial internacional ha favorecido la proliferación de diversos regímenes nacionales de eficacia - en sentido amplio- que van desde el mero valor contractual del acuerdo obtenido -que constituye la mínima eficacia que no cabe negar a las soluciones de carácter autocompositivo de controversias-, hasta la eficacia ejecutiva condicionada a la homologación del acuerdo por una autoridad pública - el juez o el notario, por la que - de acuerdo con nuestra tradición jurídicaha optado la UE en la Directiva 2008/52/CE. El amplio abanico de soluciones nacionales comprende, en el plano internacional, desde la máxima generosidad de unos pocos ordenamientos latinoamericanos que atribuyen eficacia ejecutiva directa al acuerdo logrado en mediación ${ }^{7}$, hasta el mutismo del ordenamiento

solo terminológica, quedémonos con que para la CSM «conciliación» y «mediación» son equivalentes y que lo fundamental, a los efectos de la CSM, es que el acuerdo autocompositivo se haya alcanzado «con la asistencia de uno o más terceros ("el mediador") que carezcan de autoridad para imponerles una solución» (aptdo. 3 del art. 2 CSM).

${ }^{5}$ Expresión tomada del Considerando C) de la Resolución del Parlamento Europeo, de 12 de septiembre de 2017, sobre la aplicación de la Directiva 2008/52/CE del Parlamento Europeo y del Consejo, de 21 de mayo de 2008, sobre ciertos aspectos de la mediación en asuntos civiles y mercantiles (Directiva sobre la mediación) (2016/2066(INI)).

${ }^{6}$ Vaya por delante que en este trabajo se emplean los términos «reconocimiento» y «exequátur» en su sentido más extendido, aunque comprensivo también de la homologación de acuerdos y decisiones de confección no judicial. Esto es, debe entenderse por «reconocimiento» la homologación de la decisión extranjera que le permite desplegar en el territorio del foro todos los efectos jurídicos - salvo los ejecutivos- que le sean propios, como los constitutivos, los declarativos y los jurídicoprocesales en que consiste la cosa juzgada material, mientras que el «exequátur» consiste en el procedimiento de homologación de la decisión extranjera que le permite, estrictamente, desplegar su eficacia ejecutiva [cfr., por todos, GASCón INCHAUSTI, F., "Reconocimiento y ejecución de resoluciones judiciales extranjeras en la ley de cooperación jurídica internacional en materia civil”, en Cuadernos de Derecho Transnacional (Octubre 2015), Vol. 7, No 2, p. 160)].

7 Así, Argentina, Brasil, Ciudad de México o Perú, señalados como ejemplo por C. Esplugues Mota, "La Convención de Singapur de 2018 sobre mediación y la creación de un título deslocalizado...", loc. cit., p. 59. Vid., más ampliamente, C. EspluGUES MotA, "La ejecución de los acuerdos alcanzados en el marco de un procedimiento de mediación: diferentes continentes, diferentes soluciones y un objetivo - aparentemente - común", en Revista Jurídica Digital UANDES 3/1 (2018), pp. 40-59, DOI: https://doi.org/10.24822/rjduandes.0301.4, y, más extensamente, en Mediacion Civil y Comercial. Regulacion Internacional e Iberoamericana (Civil and Commercial Mediation. International and Iberoamerican Regulation) (Table of Contents), 
norteamericano, que carece a nivel federal de ley de mediación y, a nivel estatal, de normas homogéneas sobre la eficacia ejecutiva, propiamente dicha, de los acuerdos obtenidos en mediación ${ }^{8}$.

12. Esta variedad de soluciones puede impactar negativamente en el desarrollo del tráfico comercial internacional y resulta discordante con el fomento de la mediación como medio adecuado de solución de controversias. De un lado, la incentivación de la mediación transnacional como medio rápido, barato y flexible para dirimir un problema presenta la muy valiosa ventaja -en el plano económico- de que favorece la cooperación entre las partes, permite preservar la relación comercial entablada y forjar las bases para las futuras. Desde este punto de vista, es claro que la propia mediación propicia el cumplimiento de las obligaciones asumidas por cada parte en el acuerdo finalmente obtenido'. Mas, de otro lado, también se ha observado que en el contexto del comercio internacional, en el que sujetos de diferentes culturas traban relaciones comerciales no necesariamente duraderas o sólidas, el acceso a la ejecución es uno de las principales preocupaciones, junto con la incertidumbre y los costes de resolución de la controversia, que pueden desincentivar el intercambio internacional de bienes y servicios ${ }^{10}$. Ergo, la amenaza de la vis ejecutiva del eventual acuerdo obtenido en mediación contribuye a fomentar la confianza en la mediación como método eficaz de solución de la controversia y, con ella, se elevan las opciones de cumplimiento voluntario, que pueden terminar convirtiendo en innecesaria la ulterior ejecución forzosa ${ }^{11}$.

13. Hemos llegado, así, al resultado de que, en poco menos de un quinquenio, a iniciativa de EE.UU., el grupo de trabajo II (Arreglo de Controversias) de la CNUDMI, ha alumbrado, en apenas seis sesiones -de la $63^{\mathrm{a}}$ a la $68^{\mathrm{a}}$, incl.-, celebradas en el arco temporal que discurre entre el año 2014 y el año 2018, una modificación de la ahora llamada «Ley Modelo sobre Mediación Comercial Internacional y Acuerdos de Transacción Internacionales Resultantes de la Mediación» ${ }^{12}$ y, sobre todo, la «Convención de Singapur de la Mediación» de 2019. El presente estudio está dedicado a la presentación y a un primer análisis de esta última Convención que instaura, en materia de acuerdos de mediación

\footnotetext{
Valencia, 2019.

${ }^{8}$ Los EE.UU. no cuentan con una ley federal específica de mediación, aunque sí disponen, desde 1998, con un una más general Alternative Dispute Resolution Act, de 1998 y con una amplia práctica en la aplicación de estos sistemas alternativos al proceso judicial. En la actualidad, dos asociaciones de peso -la American Bar Association y la National Conference of Commissioners on Uniform State Laws, más conocida como Uniform Law Commission- han promovido un modelo de ley uniforme de mediación, la US Uniform Mediation Act (UMA), que ha sido incorporado a varias leyes estatales y que está en vigor -al tiempo en que se escriben estas líneas - en doce Estados (Nebraska, Illinois, Iowa, New Jersey, Washington, Ohio, Utah, Vermont, District of Columbia, South Dakota, Idaho y Hawaii; el texto modelo y las diversas leyes estatales pueden consultarse en https://www.uniformlaws.org/committees/community-home?CommunityKey=45565a5f-0c57-4bba-bbab-fc7de9a59110). Ahora bien, sin perjuicio de que algún legislador estatal sí ha completado el vacío normativo en este punto, la UMA se centra, sobre todo, en preservar el privilegio de la confidencialidad de la mediación y no atribuye eficacia ejecutiva propiamente dicha al acuerdo obtenido, que tanto puede ser escrito como oral. Así pues, la eficacia por la que implícitamente ha optado este texto es la meramente obligacional que se deriva de todo contrato (así, en el mismo sentido, NAVAS Glembotzky, J. R., "El enforcement del acuerdo de mediación civil y mercantil en el ámbito internacional: Análisis, Estudio Comparado y Recomendaciones", en InDret. Revista para el análisis del Derecho, no 2/2014, pp. 24 y 25 (v.e. disponible en https://indret.com/wp-content/themes/indret/pdf/1054 es.pdf); y C. Esplugues Mota, "La Convención de Singapur de 2018 sobre mediación y la creación de un título deslocalizado...," loc. cit., p. 57).

${ }^{9}$ Estas virtudes de la mediación comercial transnacional son los atributos más destacados en la abundante literatura que ilustro - por todos- con las palabras de SchNABEL en su intervención en la 48 a sesión del grupo de trabajo CNUDMI, de 2 de julio de 2015, recogidas en T. SchnABEL, "The Singapore Convention on Mediation: A Framework...", cit. p. 2 , nota 5.

${ }^{10}$ Así, ChuA, E., "Enforcement of International Mediated Settlements without the Singapore Convention on Mediation", (2019) 31 Singapore Academy of Law Journal, special issue, p. 573.

${ }^{11}$ Desgraciadamente, la falta de datos estadísticos sobre mediación y sobre el número o frecuencia de ejecuciones forzosas a que da lugar no permite estudiar la incidencia real del incumplimiento de los acuerdos de mediación, ni los problemas de ejecución que se puedan estar planteando. Esta es también una preocupación del Parlamento Europeo, que ha dirigido una Recomendación a la Comisión para que «realice un estudio detallado sobre los obstáculos que dificultan la libre circulación de los acuerdos de mediación extranjeros en la Unión t sobre las diversas opciones para fomentar el uso de la mediación como una manera sólida, asequible y eficaz de resolver los litigios internos y transfronterizos en la Unión» (Resolución del Parlamento Europeo, de 12 de septiembre de 2017, sobre la aplicación de la Directiva 2008/52/CE, ya mencionada).

${ }^{12}$ Documentos Oficiales de la Asamblea General, Septuagésimo tercer período de sesiones (A/73/17).
} 
comercial transnacional, un régimen armonizado de libre circulación y de eficacia extraterritorial automática, sin necesidad de expediente de exequátur u homologación nacional previa por una autoridad pública: la CSM innova un «stateless instrument» (SCHNABEL) ${ }^{13} \mathrm{o}-\mathrm{en}$ expresión de Esplugues Motaun «título deslocalizado dotado de fuerza ejecutiva directa en el elenco de países que eventualmente lo ratifiquen ${ }^{14}$. Pero, antes de ver el horizonte que dibuja la Convención, elementales razones didácticas aconsejan esbozar el panorama actual desde la doble perspectiva española y europea.

\section{II. ¿Dónde estamos en materia de eficacia extraterritorial de los acuerdos de mediación?}

\section{El reconocimiento y la ejecución de la mediación en la Directiva 2008/52/CE}

\section{A) De la falta de eficacia ejecutiva de los acuerdos de mediación y su aseguramiento mediante homologación por autoridades nacionales}

14. Desde la perspectiva europea, la CSM viene a colmar lo que podría, a priori, parecer un defecto de la Directiva 2008/52/CE, del Parlamento Europeo y del Consejo, de 21 de mayo de 2008 ${ }^{15}$, sobre ciertos aspectos de la mediación en asuntos civiles y mercantiles, y, por extensión, de nuestra norma nacional de trasposición, la Ley 5/2012, de 6 de julio, de Mediación en asuntos civiles y mercantiles (en adelante, LMACM) ${ }^{16}$ : la carencia de efectos ejecutivos inmediatos, ligados a la mera constancia escrita de la solución alcanzada entre las partes en un procedimiento de mediación. Mas el tiempo y los avances habidos en materia de reconocimiento y ejecución de decisiones en el ámbito civil UE obligan a matizar -y aun a negar, como veremos- esta primera impresión.

15. Cabe recordar que la Directiva 2008/52/CE se sitúa todavía en el marco de las políticas comunitarias de facilitación del correcto funcionamiento del mercado interior a que aludía el antiguo art. 65 TCEE, que impulsaba la cooperación con repercusión transfronteriza - «en la medida necesaria para el correcto funcionamiento del mercado interior»- con el fin de mejorar e impulsar «el reconocimiento y la ejecución de resoluciones civiles y mercantiles, incluidos los extrajudiciales》 y «eliminar obstáculos al buen funcionamiento de los procedimientos civiles» ${ }^{17}$. Con el Tratado de Lisboa de 2007, el reconocimiento mutuo de decisiones en materia civil y mercantil pasó a ser un principio basilar de la construcción del espacio judicial europeo, en el que, de acuerdo ahora con el art. 71 TFUE, la UE debe garantizar - «en particular cuando resulte necesario para el buen funcionamiento del mercado interior»-, varios aspectos de su aptdo. 2 que inciden en la materia que nos ocupa, a saber: «el reconocimiento mutuo, entre los Estados miembros, de las resoluciones judiciales y extrajudiciales, así como su ejecución» [letra a)]; «una tutela judicial efectiva» [letra e)]; «la eliminación de los obstáculos al buen funcionamiento de los procedimientos civiles, fomentando si es necesario la compatibilidad de las normas de procedimiento civil aplicables en los Estados miembros» [1etra f)]; y «el desarrollo de métodos alternativos de resolución de litigios» [letra g)].

16. Pero, con todo, ni la proclamación del reconocimiento mutuo de decisiones como principio en la construcción del espacio judicial europeo, ni el desarrollo de los MARC, dispensan, por sí mismos, eficacia ejecutiva directa a las decisiones y acuerdos en materia civil y mercantil. Es precisa la voluntad política de ambicionar la eficacia ejecutiva de los acuerdos obtenidos en mediación y atribuírsela mediante instrumentos normativos de desarrollo, pues, por más que -como se ha apuntado- el clima de

\footnotetext{
${ }^{13}$ T. Schnabel, "The Singapore Convention on Mediation: A Framework...", loc. cit., p. 22.

${ }^{14}$ C. Esplugues Mota, "La Convención de Singapur de 2018 sobre mediación y la creación de un título deslocalizado...", loc. cit., p. 57.

${ }_{15}$ Diario Oficial de la Unión Europa de 24 de mayo de 2008, L 136/3 (ELI: http://data.europa.eu/eli/dir/2008/52/oj).

${ }^{16}$ Boletín Oficial del Estado núm. 162, de 7 de junio de 2012 (BOE-A-2012-9112).

${ }_{17}$ Versión consolidada publicada en Diario Oficial de la Unión Europa de 29 de diciembre de 2006, C 321E, disponible en https://eur-lex.europa.eu/legal-content/ES/TXT/HTML/?uri=OJ:C:2006:321E:FULL\&from=EN.
} 
negociación que la mediación instala entre las partes propicia el cumplimiento voluntario del acuerdo alcanzado, parece bastante razonable que la efectividad del acuerdo no dependa solo de la buena voluntad de las partes. Y, en este punto, la Directiva 2008/52/CE optó -por decirlo empleando las palabras de su Considerando 19- por «asegurar que las partes en un acuerdo escrito resultante de la mediación puedan hacer que su contenido tenga fuerza ejecutiva», para cuidar que en los asuntos transfronterizos la mediación no se convierta en «una alternativa peor que el proceso judicial» ${ }^{18}$, aunque -como veremos- ha confiado la eficacia ejecutiva a que todas las partes lo consientan.

17. La Directiva ha obligado a los Estados UE a introducir mecanismos internos para dotar de eficacia ejecutiva al acuerdo logrado en mediación, como prescribe, en términos bastante generales, el art. 6 de la Directiva 2008/52/CE, dedicado al Carácter ejecutivo de los acuerdos resultantes de la mediación, en los siguientes términos:

«1. Los Estados miembros garantizarán que las partes, o una de ellas con el consentimiento explícito de las demás, puedan solicitar que se dé carácter ejecutivo al contenido de un acuerdo escrito resultante de una mediación. El contenido de tal acuerdo se hará ejecutivo a menos que, en el caso de que se trate, bien el contenido de ese acuerdo sea contrario al Derecho del Estado miembro donde se formule la solicitud, bien la legislación de ese Estado miembro no contemple su carácter ejecutivo.

2. El contenido del acuerdo podrá adquirir carácter ejecutivo en virtud de sentencia, resolución o acto auténtico emanado de un órgano jurisdiccional u otra autoridad competente, de conformidad con la legislación del Estado miembro en el que se formule la solicitud.

3. Los Estados miembros comunicarán a la Comisión los órganos jurisdiccionales u otras autoridades competentes para recibir una solicitud de conformidad con los apartados 1 y 2.

4. Lo dispuesto en el presente artículo no afectará a las normas aplicables al reconocimiento y a la ejecución en otro Estado miembro de un acuerdo que haya adquirido carácter ejecutivo de conformidad con el apartado 1 ».

18. Así, es dable obtener la eficacia ejecutiva tanto en el Estado de origen como en el Estado requerido, en ambos casos con arreglo al Derecho del Estado miembro en el que se pida la atribución de esta eficacia. Y esta atribución está, en todo caso, supeditada -de acuerdo con el art. 6 de la Directiva 2008/52/CE- a la doble garantía consistente en que (i) conste el consentimiento explícito de todas las partes sobre la eficacia ejecutiva del acuerdo escrito resultante de la mediación («las partes, o una de ellas con el consentimiento explícito de las demás, puedan solicitar que se dé carácter ejecutivo....); y (ii) el contenido del acuerdo sea homologado por una autoridad pública, «en virtud de sentencia, resolución o acto auténtico emanado de un órgano jurisdiccional u otra autoridad competente». Cumpliéndose estas exigencias, las partes pueden pedir - no se atribuye ex lege-que el acuerdo obtenido en mediación obtenga la deseada eficacia ejecutiva que solamente cabe negar - art. 6.1. i.f.- cuando el contenido del acuerdo «sea contrario al Derecho del Estado UE requerido, incluido su Derecho internacional privado» (pues la Directiva, en palabras de su Considerando 21, «no debe alentar a las partes a eludir la legislación

${ }^{18}$ Téngase en cuenta que el aptdo. 1 del art. 2 de la Directiva 2008/52/CE define como «litigio transfronterizo» «aquel en que al menos una de las partes está domiciliada o reside habitualmente en un Estado miembro distinto del Estado miembro de cualquiera de las otras partes en la fecha en que: a) las partes acuerden hacer uso de la mediación una vez surgido el litigio, o b) un tribunal dicte la mediación, c) sea obligatorio recurrir a la mediación a tenor de la legislación nacional, o d) a efectos del artículo 5, se remita una invitación a las partes». Esta consideración de «litigio transfronterizo» la atribuye en los mismos términos el art. 3.1 LMACM, aunque importa recordar que nuestra Ley resulta aplicable a todo supuesto de mediación, ya de alcance interno o ya de carácter transnacional, al haber adoptado un «sistema monista» o único (A. L. CALvo CARAVACA, A. L., y J. Carrascosa GonzÁlez,, Derecho internacional Privado, cit., p. 176).

Por lo demás, la Directiva 2008/52/CE —debe advertirse- es una «Directiva procesal» sobre la mediación, en el sentido de que la disciplina en cuanto instrumento mismo de pacificación del asunto, sin penetrar en el terreno del Derecho aplicable al asunto objeto de la mediación. Este otro derecho se encarga de regir la validez de los derechos y obligaciones que son objeto del acuerdo de mediación y se ha de determinar con arreglo al propio sistema de Derecho Privado del Estado en que se formalice el acuerdo. Trasladado esto al ámbito espacial unieuropeo, significa que habrá que estar, normalmente, al correspondiente «Reglamento Roma» para conocer la ley aplicable ratione materiae y, en su defecto, sistema convencional y, por último, al sistema conflictual interno (vid. A. L. Calvo Caravaca, A. L., Y J. Carrascosa GonzÁlez,, Derecho internacional Privado, cit., p. 176-178). 
del Estado miembro en cuestión mediante gestiones encaminadas a dotarlo de fuerza ejecutiva en otro Estado miembro»), o cuando esta no disponga la fuerza ejecutiva del contenido del acuerdo específico.

19. En este sentido y como singularidad española, no está de más advertir que a los acuerdos de mediación objeto de nuestra Ley 5/2012 ( = los nacionales y los transfronterizos, todos) que sean elevados a escritura pública con los requisitos del art. 25 LMACM, no le son aplicables las previsiones del art. 520 LEC que condicionan la eficacia ejecutiva de los títulos extrajudiciales del art. 517 LEC a que documenten la exigencia de una obligación dineraria por cantidad determinada que exceda de 300 euros y cuyo importe esté expresado en moneda nacional, extranjera convertible o en cosa o especie computable en dinero ${ }^{19}$. La razón última hay que encontrarla en la supremacía del Derecho unieuropeo, que ha desbordado las exigencias - sobre todo, las cuantitativas, pero también las cualitativas- del art. 520 LEC; razón por la cual, con buen sentido, el legislador español ha optado por dispensar a los acuerdos de mediación elevados a escritura pública ex art. 25 LMACM la eficacia ejecutiva ilimitada que tienen de suyo - en razón de su vinculación con el derecho fundamental a la tutela judicial efectiva del art. 24.2 CE- los títulos ejecutivos de confección judicial (más, ahora, la pléyade de «asimilados»). Solo esta «artificiosa equiparación» consigue que la mediación sea una alternativa dotada de la misma eficacia práctica y transformativa (= ejecutiva) que la que puede arrojar el resultado jurisdiccional de un proceso ante los tribunales ${ }^{20}$.

20. Pues bien, como es de ver, el art. 6 de la Directiva 2008/52/CE contiene apenas un par de importantes normas mínimas de armonización que los diferentes legisladores nacionales, sin embargo, han traspuesto de forma desigual, como luego ilustraremos con el ejemplo italiano y el español ${ }^{21}$. Retengamos, mientras tanto, que la Directiva 2008/52/CE (art. 6.4) deja a salvo la aplicación de los restantes regímenes unieuropeos de reconocimiento y ejecución de resoluciones en materia civil y mercantil, como el régimen general contenido - ahora- en el vigente Reglamento 1215/2012, o los regímenes particulares que incorporan los diferentes Reglamentos sectoriales. Así lo anuncia el propio Considerando 20 de la Directiva 2008/52/CE: «El contenido de los acuerdos resultantes de la mediación que hayan adquirido carácter ejecutivo en un Estado miembro debe ser reconocido y declarado ejecutivo en los demás Estados miembros, de conformidad con la legislación comunitaria o nacional aplicable, por ejemplo sobre la base del Reglamento (CE) $n^{\circ} 44 / 2001$ del Consejo, de 22 de diciembre de 2000, relativo a la competencia judicial, el reconocimiento y la ejecución de resoluciones judiciales en materia civil y mercantil, o del Reglamento (CE) $n^{\circ} 2201 / 2003$ del Consejo, de 27 de noviembre de 2003, relativo a la competencia, el reconocimiento y la ejecución de resoluciones judiciales en materia matrimonial $y$ de responsabilidad parental».

${ }^{19}$ No puedo entrar a exponer con cierto detenimiento las exigencias del art. 520 LEC y su interpretación jurisprudencial, que puede verse en B. SÁNCHEz López, Ejecución dineraria: liquidez, embargo y realización forzosa, Madrid, 2019, pp. 33-55. Pero quiero indicar que, al margen de todo procedimiento de mediación, las partes siempre tendrán la posibilidad de constituir un título extrajudicial mediante escritura pública que cumpla con estas exigencias del art. 520 LEC. En el mismo sentido, vid. V. Pardo Iranzo, La ejecución de lo acordado en mediación, ed. Aranzadi, Madrid, 2013, separata electrónica, p. 17, nota 51.

${ }^{20}$ Coinciden en el mismo sentido de no resultar aplicables las exigencias del art. 520 LEC a la escritura de acuerdo obtenido en mediación tras la promulgación de la LMACM, MARTín PASTOR, J., "La reforma del proceso civil de ejecución por el Real Decreto-Ley 5/2012”, Diario La Ley, núm. 7862, 21 de mayo de 2012; y V. PARdo Iranzo, La ejecución de lo acordado en mediación, cit., p. 26.

${ }^{21}$ Para un estudio más amplio del panorama de la mediación en los Estados UE, me remito, sin ningún ánimo de exhaustividad, a C. Esplugues Mota, "Civil and Commercial Mediation in the EU after the Transposition of Directive 2008/52/EC", en C. Esplugues Mota, Civil and Commercial Mediation in Europe, vol. II. Cross-Border Mediation, Cambridge, 2014, pp. 485-771; J. R. NAVAS GLEmbotzKy, "El enforcement del acuerdo de mediación civil y mercantil en el ámbito internacional...., loc. cit., pp. 1-34; y el estudio de la Dirección General de Políticas Interiores de la Unión titulado Rebooting the Mediation Directive: Assessing the Limited Impact of its Implementation and Proposing Measures to Increase the Number of Mediations in the $E U$ («Relanzamiento» de la Directiva sobre la mediación: evaluación del impacto limitado de su aplicación y propuesta de medidas destinadas a aumentar el número de mediaciones en la Unión), Bruselas, 2014, espec. pp. 16-118 ( v. e. disponible en http://www.europarl.europa.eu/studies), donde se compendian informes de más de ochocientos expertos procedentes de casi todos los Estados UE. Las singulares leyes nacionales de trasposición de la Directiva 2008/52/CE pueden ser consultadas en el portal Eur-Lex (https://eur-lex.europa.eu/legal-content/ES/NIM/?uri=uriserv:OJ.L_.2008.136.01.0003.01.SPA). 


\section{B) Los avances en materia de reconocimiento y ejecución de decisiones y acuerdos de otros instru- mentos europeos}

21. Por consiguiente, la Directiva $2008 / 52 / C E$, a diferencia de la CSM, no confiere por sí misma carácter ejecutivo a las obligaciones resultantes del acuerdo transnacional de mediación: facilita la obtención de la eficacia ejecutiva, pero no se la atribuye ex lege al acuerdo en sí mismo considerado ${ }^{22}$. Ahora bien, en honor a la justicia, no puede valorarse negativamente esta decisión de política legislativa de la Directiva de mediación.

22. En primer lugar, no cabe olvidar que al tiempo de promulgarse la Directiva apenas habían transcurrido cuatro años desde que el Reglamento (CE) n ${ }^{\circ}$ 805/2004 del Parlamento Europeo y del Consejo, de 21 de abril de 2004, por el que se establece un título ejecutivo europeo para créditos no impugnados (en adelante, RTEE) ${ }^{23}$, prescindió por primera vez del exequátur o previa declaración de ejecutividad en el espacio europeo. Este paso - que, realidad, debutó con la ejecutabilidad automática de las resoluciones judiciales relativas al derecho de visitas y a la restitución de menores- no ha culminado hasta la generalización de la supresión de exequátur por obra del Reglamento 1215/2012, del Parlamento Europeo y del Consejo de 12 de diciembre de 2012, relativo a la competencia judicial, el reconocimiento y la ejecución de resoluciones judiciales en materia civil y mercantil ${ }^{24}$, también conocido como Reglamento Bruselas I bis (RB I bis). Así pues, valorado en su justo contexto, no hay que extrañarse de que, en materia de reconocimiento y ejecución de acuerdos resultantes de mediación transnacional, la Directiva 2008/52/CE no fuera más lejos y se conformara con introducir expedientes de facilitación de efectos ejecutivos al acuerdo mediado en asuntos transfronterizos.

23. Pero es que, además y en segundo lugar, pese a este aparente defecto, la Directiva no ocultaba que, en la medida en que dejaba a salvo la aplicación de otros instrumentos más generosos, la libre circulación de los acuerdos de mediación transnacionales quedaba doblemente asegurada en el espacio europeo: de un lado, por la mencionada facilitación del acceso a la eficacia ejecutiva en el Estado requerido, con arreglo a su Derecho, y también, de otro lado, por las facilidades de circulación del acuerdo ya dotado en el Estado de origen de eficacia ejecutiva, al amparo de las normas comunitarias de reconocimiento y ejecución que ya estaban disponibles en otros instrumentos europeos entonces en vigor y cuya evolución posterior ha tendido hacia la eficacia extraterritorial automática.

24. El desarrollo, en efecto, del marco europeo dedicado al reconocimiento y la ejecución en estos otros instrumentos no ha hecho, desde entonces, otra cosa que fomentar la libre circulación de categorías cada vez más amplias de resoluciones judiciales, decisiones y documentos públicos en materia civil y mercantil, sin necesidad de expedientes - abreviados o no- de declaración de ejecutividad en el Estado UE en el que se desea aplicar. Se ve con claridad solo con ilustrarlo con unos cuantos Reglamentos que se encontraban en vigor al tiempo de la Directiva de mediación.

\section{a) El reconocimiento y la ejecución de resoluciones judiciales en materia civil en el marco del RB I bis}

25. Al tiempo de promulgarse la Directiva $2008 / 52 / C E$, el ya derogado Reglamento (CE) $n^{\circ}$ 44/2001 del Consejo, de 22 de diciembre de 2000, relativo a la competencia judicial, el reconocimiento

${ }^{22}$ El art. 6 de la Directiva 2008/52/CE no proporciona ningún criterio dedicado al «reconocimiento» de los acuerdos resultantes de la mediación, por la indefinición de la eficacia no ejecutiva que deba atribuirse a los acuerdos de transacción y a los documentos públicos en que se formalicen, cuestión que será tratada más adelante.

${ }^{23}$ Diario Oficial de la Unión Europa de 30 de abril de 2004, DO L 143 (ELI: http://data.europa.eu/eli/reg/2004/805/200812-04).

${ }^{24}$ Diario Oficial de la Unión Europa de 20 de diciembre de 2012,L351/1 (ELI: http://data.europa.eu/eli/reg/2012/1215/201502-26). 
y la ejecución de resoluciones judiciales en materia civil y mercantil ${ }^{25}$, subordinaba el reconocimiento y la ejecución de documentos públicos con fuerza ejecutiva y transacciones a la tramitación -v. arts. $57 \mathrm{y}$ 58- de un procedimiento simplificado de declaración de ejecutividad del que, a la postre, ha terminado prescindiendo el nuevo Reglamento 1215/2001, en vigor desde el 10 de enero de 2015.

26. En la actualidad, los arts. 58 a 60, incl., del Reglamento 1215/2012 dotan de eficacia extraterritorial a los dos tipos de títulos que pueden documentar un acuerdo obtenido en mediación, a saber: (i) a los «documentos públicos con fuerza ejecutiva» en el Estado de origen, cuya definición autónoma sigue la caracterización trazada en la precursora STJUE de 17 de junio de 1999, C-260/97, Unibank A/S, bajo la vigencia todavía del Convenio de Bruselas, que ahora se recoge en el art. 4.3 RB I bis, esto es, se tiene por tal al «documento formalizado o registrado oficialmente como documento público en el Estado miembro de origen y cuya autenticidad: i) se refiera a la firma y al contenido del instrumento, y ii) haya sido establecida por una autoridad pública u otra autoridad habilitada a tal fin»; y (ii) a los acuerdos de transacción judiciales siempre que estén dotados de eficacia ejecutiva en el Estado de origen.

27. A ambas clases de títulos ejecutivos les garantizan los arts. 58 y 59 del Reglamento 1215/2012 la extensión de su eficacia ejecutiva «en los demás Estados miembros sin necesidad de declaración de fuerza ejecutiva», salvo que su ejecución «sea manifiestamente contraria al orden público en el Estado miembro requerido», en cuyo caso, a petición de la persona contra la que se haya instado la ejecución $-y$ no de oficio- podrá denegarse su reconocimiento o su ejecución. La libre circulación de estos títulos ex RB I bis se basa en la expedición, a instancia de parte interesada, de un certificado normalizado, por parte de la autoridad pública o el tribunal del Estado miembro de origen, que contiene un resumen de la obligación ejecutiva consignada en el documento público o del acuerdo entre las partes consignado en la transacción judicial (art. 60).

28. La ejecución que deba desarrollarse en España se efectúa -como no puede ser de otro modo por el carácter territorial de la ejecución forzosa - con arreglo a las normas de la $\mathrm{LEC}^{26}$. Hay que acudir a la Disposición Final 25 LEC, para encontrar las normas que facilitan la aplicación del RB I bis en España, en cuya sede los aptdos. 7 y 8 reproducen casi literalmente las reglas del Reglamento 1215/2012 que confieren automáticamente y sin necesidad de una declaración específica la eficacia ejecutiva en España de los documentos públicos y transacciones judiciales que ya la tuvieran en su Estado UE de origen.

29. La única particularidad que supone la ejecución en España de un acuerdo de mediación transfronterizo europeo, consiste en que - sin perjuicio de la oposición a la ejecución que cabe oponer al amparo de la LEC- el ejecutado puede suscitar la denegación de la ejecución del título extranjero por causa de contrariedad del orden público mediante demanda de juicio verbal, ante el Juzgado de Primera Instancia que conozca de la ejecución, con las especialidades recogidas en el aptdo. 4 de la mencionada Disposición Final $21^{\mathrm{a}} \mathrm{LEC}^{27}$.

\footnotetext{
${ }^{25}$ Diario Oficial de la Unión Europa de 16 de enero de 2001, DO L 12 (http://data.europa.eu/eli/reg/2001/44/oj).

${ }^{26}$ En España, la actividad ejecutiva que se dispensa a través del proceso de ejecución consistente en la realización forzosa de derechos, obligaciones y responsabilidades de naturaleza civil -en sentido amplio-, está encomendada con carácter exclusivo y excluyente a los tribunales ex art. 117.3 CE, en el entendimiento - que arranca de la Constitución de 1812, cfr. art. 245- de que, en garantía de los justiciables, los tribunales ostentan el monopolio de la función que anacrónicamente sigue describiendo la Constitución vigente como «juzgar y hacer ejecutar lo juzgado». Así es en España, pero cada Estado UE es muy libre de establecer un sistema diferente de «enforcement», como puede verse en Hess, B., "Different enforcements structures", en C. H. VAN RheE y A. Uzelac, Enforcement and Enforceability. Tradition and Reform, Oxford, 2010, pp. 41 y ss., espec. 44-48.

${ }^{27}$ No hace al caso extenderse en mayores explicaciones sobre el régimen de reconocimiento y ejecución del RBI bis; para un conocimiento más amplio, remito al lector a, entre otros, A. L. Calvo Caravaca y J. Carrascosa González, Derecho internacional Privado, cit., pp. 654 y ss., espec. pp. 713-718; F. M. GARCIMARTín AlfÉreZ, Derecho internacional privado, 3. ${ }^{a}$ ed., Cizur Menor, 2016, pp. 252y ss.; y F. GASCón Inchausti, Reconocimiento y ejecución de resoluciones extranjeras en el nuevo Reglamento Bruselas I Bis, Valencia, 2016.
} 


\section{b) La circulación del título ejecutivo europeo de créditos no impugnados}

30. También se encontraba en vigor, al tiempo de promulgarse la Directiva de mediación, el Reglamento (CE) n ${ }^{\circ} 805 / 2004$, que fue el precursor de la expedición, por parte de las autoridades del Estado de origen, del correspondiente «certificado de título ejecutivo europeo» en el que se basa la libre circulación en el espacio judicial europeo de toda decisión civil o mercantil que documente la exigencia de un crédito dinerario líquido no impugnado por el deudor y que haya sido aprobado judicialmente o conste en documento público con eficacia ejecutiva en el Estado de origen; esto es, también los que documenten acuerdos resultantes de una mediación.

31. En aras a potenciar la tutela del crédito dinerario en el ámbito comunitario, el RTEE instauró un procedimiento europeo con normas mínimas uniformes de carácter procesal cuya aplicación permite el inmediato reconocimiento y la ejecución en los demás Estados UE de una resolución certificada como título ejecutivo europeo en el Estado miembro de origen, sin necesidad de «ninguna declaración de ejecutividad y sin posibilidad alguna de impugnar su reconocimiento» (art. 5). Y abrió esta puerta de eficacia extraterritorial automática también a los acuerdos de transacción judicial (art. 24) y a los documentos públicos de eficacia ejecutiva (art. 25), sobre la base de la expedición de dos certificados estandarizados distintos (los Anexos II y III, respectivamente), cuya emisión en España regula la Disposición Final $21^{\mathrm{a}} \mathrm{LEC}^{28}$.

32. En este punto, conviene no perder de vista que el concepto autónomo de «documento público de eficacia ejecutiva» que ofrece el art. 4.3 RTEE permitió adelantar, en su día, la libre circulación, como título ejecutivo europeo, de todo acuerdo - con mediación, o no, de un tercero- que conste en «documento formalizado o registrado como documento público con fuerza ejecutiva, y cuya autenticidad: i) se refiera a la firma y al contenido del instrumento, y ii) haya sido establecida por un poder público u otra autoridad autorizada con este fin por el Estado miembro de donde provenga; o bien b) un acuerdo en materia de obligaciones de prestar alimentos, celebrado ante las autoridades administrativas o formalizado por ella».

33. Al tiempo de promulgarse el RTEE y hasta la vigencia de la Ley $5 / 2012$ de mediación, el «documento público con fuerza ejecutiva» susceptible de ser certificado como título ejecutivo europeo incluía la escritura pública incardinable genéricamente en el ordinal $4^{\circ}$ del art. 517 LEC siempre que documentara la exigencia de una obligación dineraria que reuniese los ya mencionados requisitos del art. 520 LEC. Desde la Ley 5/2012, la emisión notarial del certificado de título ejecutivo europeo a que se refiere el aptdo. 3 de la Disposición Final $21^{\mathrm{a}} \mathrm{LEC}$ ha pasado a tener un doble fundamento, pues puede hacerse: (i) como hasta ahora, con base en la genérica escritura pública del ordinal $4 .^{\circ}$ del art. 517 LEC siempre que concurran los requisitos del art. 520 LEC; y (ii) con base en el otorgamiento de la específica escritura pública del art. 25 LMACM, que es, ahora, el «documento público de eficacia ejecutiva» que debe otorgarse para que obligaciones dinerarias comprendidas en un acuerdo de mediación transnacional pueda dar acceso a la expedición del certificado de título ejecutivo europeo, como presupuesto de su posterior circulación en el espacio UE al amparo de este Reglamento.

34. Es interesante observar cómo, en un sistema reforzado de confianza mutua como el unieuropeo, la innovación de dotar de eficacia ejecutiva al acuerdo de mediación elevado a escritura pública con los requisitos del art. 25 LMACM, efectuada dentro del escrupuloso respeto a la primacía del Derecho europeo, ha ampliado el radio de acción del RTEE. Ahora, el otorgamiento de esta específica escritura del art. 25 LMACM -y no solo la de una genéricamente incardinable en el ordinal $4^{\circ}$ del art. 517 LEC con los

\footnotetext{
${ }^{28}$ Un estudio más extenso del RTEE, efectuado desde las filas del Derecho procesal, puede ver en F. GASCón InCHAUSTI, El Título Ejecutivo Europeo para Créditos No Impugnados, Madrid, 2005, espec. pp. 213-229; y C. SENÉs MotILlA, "El título ejecutivo europeo para créditos no impugnados", en A. DE LA OLIVA SANTOS (dir.), Derecho Procesal Civil Europeo. Volumen III. Tutela judicial del crédito en la Unión Europea, vol. III, Cizur Menor, 2011, pp. 31-125.
} 
requisitos del art. 520 LEC - constituye el presupuesto de ejecutividad (= el «documento público con fuerza ejecutiva») al que el art. 25.2 RTEE vincula la expedición del título ejecutivo europeo, sin necesidad -nótese bien- de que el contenido del acuerdo deba superar el anacrónico umbral de 300 euros (que se impuso, en su día, para hacerlo coincidir con la competencia objetiva de unos Juzgados municipales que ya no existen, razón por la cual más valdría eliminarlo). Eso sí, como requisitos específicos para el otorgamiento de esta escritura figuran la necesidad de incorporar el acuerdo firmado por las partes, más las copias de las actas de la sesión constitutiva y de la final del procedimiento de mediación (art. 25 LMACM).

35. Por lo demás, permanece invariable la posibilidad alternativa de certificar como título ejecutivo europeo la transacción judicial, que, de acuerdo con las previsiones de la Disposición Final $21^{\mathrm{a}}$ LEC, corresponde expedir en España, mediante providencia, al tribunal que la aprobó (aptdos. 1 y 2).

\section{c) El reconocimiento y la ejecución en materia de responsabilidad parental y sustracción de me- nores}

36. Otro de los instrumentos que, al tiempo de promulgarse la Directiva 2008/52/CE, también se encontraba vigente $-\mathrm{y}$ todavía se encuentra, hasta el día 1 de agosto de 2022- es el Reglamento CE $\mathrm{n}^{\circ}$ 2201/2003, del Consejo, de 27 de noviembre de 2003, relativo a la competencia, el reconocimiento y la ejecución de resoluciones judiciales en materia matrimonial y de responsabilidad parental. Este Reglamento incluye, de un lado, un régimen privilegiado de reconocimiento y ejecutividad automático a las decisiones en materia de responsabilidad parental y sustracción de menores, basado en su ejecutividad inmediata (v. arts. 40-42); y junto a él, incluye, de otro lado, un régimen ordinario de reconocimiento y ejecución del resto de resoluciones (art. 21) y de documentos públicos y acuerdos dotados de eficacia ejecutiva en el Estado de origen (art. 46 ), que requieren de un procedimiento de declaración de ejecutividad en el Estado requerido, al que le quedan los días contados.

37. A partir del 1 de agosto de 2022, al amparo del art. 65.2 del nuevo Reglamento UE 2019/1111 del Consejo, de 25 de junio de 2019, relativo a la competencia, el reconocimiento y la ejecución de resoluciones en materia matrimonial y de responsabilidad parental, y sobre la sustracción internacional de menores, tendrán eficacia extraterritorial directa - en todo el territorio UE- los acuerdos alcanzados en materia de responsabilidad parental que por sí mismos tengan eficacia ejecutiva en el Estado UE de origen. Con toda claridad, el citado art. 65.2 dispone que «los documentos públicos y los acuerdos en materia de responsabilidad parental que tengan efecto jurídico vinculante y tengan fuerza ejecutiva en el Estado miembro de origen se reconocerán y ejecutarán en otros Estados miembros sin que se requiera ninguna declaración de fuerza ejecutiva (...)».

38. El cambio en una materia como ésta, en la que la mediación familiar ha demostrado su eficiencia como instrumento pacificador de relaciones duraderas ${ }^{29}$, es sustancial. La eficacia transfronteriza automática de los acuerdos de responsabilidad parental que se avecina deja atrás el régimen de reconocimiento y ejecución del Reglamento CE $n^{\circ}$ 2201/2003 -aplicable a los acuerdos que adquieran fuerza ejecutiva hasta el día 1 de agosto de 2022-, que se basa, con carácter general, en exigir, en el Estado de origen, que se trate de un documento público o de una transacción que tengan eficacia ejecutiva y que se sometan, en el Estado requerido, a la previa declaración de ejecutividad, regulada en la Sección 2. ${ }^{a}$ del Capítulo III del Reglamento. Solo escapan de esta exigencia las resoluciones y acuerdos relativos al derecho de visita y a la restitución de un menor, a los que el Reglamento 2201/2003 atribuyó, de forma precur-

\footnotetext{
${ }^{29}$ Así se ha puesto de manifiesto, entre otros, en el estudio de la Comisión titulado «Study for an evaluation and implementation of Directive 2008/52/EC - the "Mediation Directive"》 (Estudio para la evaluación y aplicación de la Directiva 2008/52/ CE - la «Directiva sobre la mediación»), Luxemburgo, 2016, p. 26 (DOI 10.2838/240354, v. e. disponible en https://op.europa. eu/s/n77w); y en la Conclusión 7 de la Resolución del Parlamento Europeo de 12 de septiembre de 2017, sobre la aplicación de la Directiva 2008/52/CE del Parlamento Europeo y del Consejo, de 21 de mayo de 2008, ya citada.
} 
sora, un régimen privilegiado de «fuerza ejecutiva en otro Estado miembro sin que se requiera ninguna declaración que le reconozca fuerza ejecutiva» (arts. 41.1 y 42.1), que es el régimen que el nuevo Reglamento 2019/1111 ha dispuesto extender al resto de resoluciones y asuntos objeto de este Reglamento.

\section{La tendencia europea hacia la facilitación de la ejecutividad de decisiones en materia civil sobre la base de títulos y documentos de eficacia ejecutiva en el Estado UE de origen: una cuestión de garantías}

39. Así pues, la coexistencia de la Directiva 2008/52/CE con otros instrumentos europeos que contienen normas relativas al reconocimiento y la ejecución de acuerdos y que las han evolucionado, ha terminado fortaleciendo la circulación de los acuerdos de mediación objeto de la Directiva. Es importante señalar esta coexistencia, porque los más modernos Reglamentos sectoriales han seguido la tendencia de prescindir de procedimiento de homologación o exequátur en el Estado requerido, sobre la base de verificar ciertos controles de legalidad, fehaciencia y autenticidad en la formación del título en el Estado de origen.

40. Esto pone de manifiesto que, al cabo de más de una década desde la promulgación de la Directiva 2008/52/CE, la decisión del legislador unieuropeo de no dotar directamente de eficacia ejecutiva a los acuerdos obtenidos en mediación y obligar a los Estados miembros a que introduzcan expedientes que permita atribuírselos, no ha quedado desfasada, como, en apariencia, podría parecer. Las posibilidades de circulación de estos acuerdos formalizados en transacciones judiciales y en documentos públicos dotados de eficacia ejecutiva en el Estado de origen se han ido actualizando de forma indirecta y paulatina, en la medida en que se ha reforzado la confianza mutua entre los Estados miembros y se ha facilitado el reconocimiento y la ejecución en el espacio judicial europeo; plano en el que legislador europeo es cada vez más receptivo a allanar el acceso a la tutela ejecutiva, en un proceso que retroalimenta la construcción del espacio judicial común civil europeo.

41. No parece descabellado augurar que este sea el camino que transite en el futuro el legislador europeo en materia de reconocimiento y ejecución de decisiones en asuntos civiles y mercantiles y que se basa en la exigencia de un «título de calidad» de eficacia ejecutiva en el Estado de origen, como presupuesto para permitir su circulación en el espacio UE sin necesidad de exequátur. Este camino, de hecho, ya lo ha emprendido el legislador español de la Ley 29/2015, de 30 de julio, de cooperación jurídica internacional en materia civil (LCJI) ${ }^{30}$, para la ejecución en España de documentos públicos extranjeros conforme al régimen legal interno (vid. arts. 56 y 57).

42. Lo que permanece invariable en los distintos Reglamentos que regulan el reconocimiento y la ejecución de decisiones en materia civil -y así debe ser, porque en ello radica el fundamento de la ejecutividad y, con ella, la licitud de la ejecución forzosa- es la doble exigencia de que el acuerdo alcanzado cuente con la intervención de un juez o de un notario y que tenga aparejada la eficacia ejecutiva en el Estado de origen, como alternativa a acudir al Estado requerido y formalizar allí el acuerdo con las mismas garantías para conseguir los efectos ejecutivos.

43. La intervención del juez o del notario y la exigencia de que el documento tenga aparejada eficacia ejecutiva no son cuestiones menores, sino muy importantes e íntimamente relacionadas entre sí. Todo sistema de ejecución de títulos ejecutivos extrajudiciales está fundamentado en una relación proporcionalmente inversa entre, de un lado, los requisitos de fiabilidad o calidad del documento de formación no judicial que permite fundar la ejecución forzosa y, de otro, la amplitud y naturaleza de los motivos de oposición que se consentirán alegar al ejecutado, de tal suerte que: (i): a mayor calidad del documento, menor ámbito de discusión debe permitirse; y (ii) en sentido contrario, a menor calidad del

${ }^{30}$ Boletín Oficial del Estado núm. 182, de 31 de julio de 2015 (BOE-A-2015-8564). 
documento, mayor número de motivos de oposición o más amplios hay que reconocer al ejecutado, en aras a garantizar un proporcionado derecho de defensa.

44. En este punto, no cabe sino observar que la formación misma de la noción de «documento público de eficacia ejecutiva» es fruto, en la cultura europea de base romano-germánica, de una larga «evolución virtuosa» que arranca en la Edad Media y que tuvo por finalidad facilitar el tráfico jurídicoeconómico entre las florecientes ciudades centroeuropeas e italianas. La evolución del primitivo pactum executivum o de la cláusula guarentigia -generalizados en contratos privados y reconocimientos de deuda - ha forjado los actuales títulos ejecutivos de origen extrajudicial - en España, a partir de las Ordenanzas de Sevilla de 1360, del Rey Pedro I ${ }^{31}$-, para permitir al acreedor franquear la puerta del proceso de ejecución (de tipo dinerario, en España), con distinta intensidad y ámbito de contradicción a lo largo del tiempo. Aludo a este breve apunte histórico porque evidencia que solo en muy excepcionales y raros casos la actividad ejecutiva puede desatarse con base en la presentación de meros documentos privados. Y cuando esto sucede - nótese bien- no sólo se rompe con una larga tradición que es la que ha revestido al título ejecutivo de las garantías del control de legalidad, fehaciencia y autenticidad que supone la intervención de la autoridad pública, sino que también se somete el proceso de ejecución a una desnaturalización que pone en riesgo su eficacia, como forzosa consecuencia del ensanchamiento de la cognición judicial que traigan los motivos de oposición, tanto atinentes a los requisitos formales del instrumento, como a los de validez o eficacia del negocio subyacente.

45. En la actualidad, tras la profunda sistematización en España de la ejecución civil en el año 2000 por obra de la LEC, lo más próximo a un documento privado de eficacia ejecutiva son los títulos cambiarios, y ello en razón de los criterios uniformes impuestos en los Convenios de Ginebra del pasado siglo. No es inoportuno recordarlo ahora, con ocasión de la entrada en vigor de la CSM, porque el peculiar régimen jurídico uniforme del título cambiario (cuya actuación supone, de plano, la adopción del embargo de bienes y el requerimiento de pago al deudor, al que se le ofrece un abanico amplio de motivos de oposición cambiaria) explica que en España haya pasado de ser considerado un «título ejecutivo» en la anterior LEC de 1881 (art. 1429.4 ${ }^{\circ}$ LEC), a constituir ahora un tertium genus que da lugar a un proceso especial de tutela del crédito regulado en los arts. 819 y ss., que se encuentra a caballo entre el proceso declarativo y el proceso de ejecución y que permite que la alegación de los motivos de oposición cambiaria se resuelvan con todas las garantías de la cosa juzgada material. Otros países, en cambio - vid. el art. 474.2 del Codice di procedura civile italiano, en adelante $c p c-$, siguen acomodando la efectividad de los títulos cambiarios en el seno del proceso de ejecución, aunque, a los ojos de un procesalista español, esto se explica por razones que fundamentalmente tienen que ver con la laxa estructura y la amplitud de la oposición que cabe suscitar en el seno de su proceso de ejecución (cfr. arts. 615 y 617 cpc italiano). En un estadio próximo - si no el mismo para algunos autores ${ }^{32}-$ se encuentra el trato que el proceso monitorio dispensa a todo crédito dinerario líquido cuya exigencia se acredite prima facie mediante determinados documentos privados «usuales» (cfr. art. 812 LEC), cuya finalidad es, precisamente, facilitar la creación de un título ejecutivo ante la falta de contestación del deudor; el resultado que arroje será, invariablemente, un título de ejecución bien de origen judicial, si ha sido obtenido con intervención de los tribunales, o de bien de origen extrajudicial, si lo ha sido en el expediente notarial de los arts. 70 y 71 de la Ley Notarial.

46. Como se ve, la construcción de un «título ejecutivo» de «calidad» condiciona la eficiencia del sistema de ejecución; la relación entre estos dos términos está siempre, a la postre, balanceada. Por

\footnotetext{
${ }^{31}$ Cfr., por todos, V. FAirén Guillén, "Un nuevo descubrimiento sobre la historia del juicio ejecutivo en España: el ordenamiento sevillano de 1360", en Estudios de Derecho procesal, Madrid, 1955, pp. 553 y ss.; J. MonTERo ArocA, Herencia procesal española, México, 1994, p. 83; y M. SERrano MAsir, El juicio ejecutivo cambiario, Barcelona, 1997, pp. 21-23.

32 Así, p. ej., Á. Bonet Navarro [“Tema 39. Proceso monitorio cambiario”, en M. Ortells Ramos (dir.), Derecho procesal civil, $15^{\mathrm{a}}$ ed., Cizur Menor, 2016, v.e.], quien argumenta que la naturaleza del juicio cambio es monitoria, lo que remite al problema de definir cuál sea esta naturaleza, si declarativa, si ejecutiva o si un tertium genus, como en su día defendió F. CARNelutTi (vid., por todos, E. Garbagnati, Il procedimiento d'ingiunzione, 2. a ed, ed. Giuffrè, 2012, pp. 21 y ss).
} 
ello, volviendo de nuevo al acuerdo de mediación formalizado en documento público de eficacia ejecutiva, hay que felicitarse de que la tramitación parlamentaria de la Ley 5/2012 torciera la idea inicial del Anteproyecto gubernamental de 19 de febrero de $2010^{33}$ que pretendía atribuir eficacia ejecutiva directa al acuerdo de mediación de carácter interno, con tal que: (i) constara por escrito firmado por las partes y por el mediador (art. 28.2 y 3); y (ii) que a la demanda de ejecución se acompañara el acuerdo de mediación y copia de las actas de la sesión constitutiva y final del procedimiento (art. 30.1). Esta idea fue objeto de duras críticas desde bien temprano, tanto por el Consejo General del Poder Judicial en su informe de 19 de mayo de $2010^{34}$, como por el Consejo de Estado, en el suyo de 17 de febrero de $2011^{35}$, sin olvidar las dirigidas por la doctrina ${ }^{36}$. Finalmente, con buen sentido, además de la homologación judicial del acuerdo obtenido en mediación (art. 25.4 LMACM), la Ley optó por anudar la eficacia ejecutiva al otorgamiento por un notario de escritura pública del acuerdo obtenido en mediación, al que deben concurrir las partes para expresar su concurso de voluntades y aportar «el acuerdo de mediación (...) y copia de las actas de la sesión constitutiva y final del procedimiento, sin que sea necesaria la presencia del mediador» (art. 25.1.II LMACM). La función del notario en la confección del instrumento -se encargan de precisar los aptdos. 2 y 3 del art. 26 LMACM- consiste en «verificar(á) el cumplimiento de los requisitos exigidos en esta Ley y que su contenido no es contrario a Derecho» en todo supuesto, y, además, «cuando el acuerdo de mediación haya de ejecutarse en otro Estado, además de la elevación a escritura pública, será necesario el cumplimiento de los requisitos que, en su caso, puedan exigir los convenios internacionales en que España sea parte y las normas de la Unión Europea».

47. Hoy en día, inmersos en un contexto en el que el reconocimiento y la ejecución en el espacio civil europeo tiende a reforzar la eficacia extraterritorial de los documentos públicos dotados de eficacia ejecutiva en el Estado de origen, es aún más necesario preservar todas y cada una de las garantías que los invisten ab origine de eficacia ejecutiva. De ello depende la confianza mutua que está en la base del nuevo «régimen liberalizado» de circulación de acuerdos y documentos que ha llegado a los nuevos Reglamentos unieuropeos. Si - como parece- este es nuestro horizonte más próximo, resulta del todo apropiado no cejar en el empeño de defender el otorgamiento de escritura pública como título idóneo para atribuir eficacia ejecutiva al acuerdo obtenido en mediación, como, muy recientemente, ha vuelto a recordar Senés Motilla con estas palabras que no quiero omitir: «una cosa es la eficacia obligacional del acuerdo alcanzado en el procedimiento de mediación-(art. 1258 CC; arts. 23.1. II y 3.II LMACM)-y, otra diferente es la atribución de fuerza ejecutiva que la Ley confiere a su elevación a escritura pública, en razón, precisamente, de la intervención del notario y del control por éste del contenido del acuerdo (...) La subordinación de la fuerza ejecutiva del acuerdo de mediación a su elevación a escritura pública obedece a la elemental seguridad jurídica que reporta la intervención del notario autorizante, en el doble sentido de tener éste que comprobar que el contenido del acuerdo responde a la voluntad real de las partes y que no es contrario a Derecho» ${ }^{37}$.

\footnotetext{
${ }^{33}$ El texto de este Anteproyecto, impulsado por el entonces Excmo. Sr. Ministro D. Francisco CaAmaño, puede consultarse en https://estaticos.expansion.com/estaticas/documentos/2010/04/mediacion.pdf.

34 V. e. disponible en http://www.poderjudicial.es/stfls/cgpj/COMISI\%C3\%93N\%20DE\%20ESTUDIOS\%20E\%20INFORMES/INFORMES\%20DE\%20LEY/FICHERO/009.10_1.0.0.pdf

${ }_{35}$ V. e. disponible en https://www.boe.es/buscar/doc.php?id=CE-D-2010-2222.

36 Vid. GonzÁlez Cuéllar, N., "La limitada ejecutoriedad de la escritura pública: Incoherencia del sistema", en El Notario del siglo XXI. Revista bimestral del Ilustre colegio Notarial de Madrid, $\mathrm{N}^{\mathrm{o}} 38$, julio-agosto 2011, v.e. disponible en https:// www.elnotario.es/index.php/hemeroteca/revista-38/759-la-limitada-ejecutoriedad-de-la-escritura-publica-incoherencia-del-sistema-0-5261588716191788; SANTOS ViJANDE, J. M., "Tratamiento procesal de la mediación y eficacia ejecutiva del acuerdo de mediación en la Ley 5/2002”, en Riedpa: Revista Internacional de Estudios de Derecho Procesal y Arbitraje, núm. 1, 2013 , v.e. disponible en http://www.riedpa.com/COMU/documentos/RIEDPA11303.pdf; y TorRes EscámEz, S., "Ejecuta como sea (o el carácter ejecutivo del documento privado de mediación)", en El Notario del siglo XXI. Revista bimestral del Ilustre colegio Notarial de Madrid, $\mathrm{N}^{\mathrm{o}} 38$, julio-agosto 2011, v.e. disponible en https://www.elnotario.es/101-hemeroteca/revistas/revista-38/765ejecuta-como-sea-o-el-caracter-ejecutivo-del-documento-privado-de-mediacion-0-0240556048453372.

37 C. Senés Motilla Las disposiciones generales sobre la ejecución forzosa en la Ley de Enjuiciamiento Civil, MADRID, 2019, Р. 55.
} 


\section{De los silencios y de otras omisiones de la Directiva 2008/52/CE de Mediación}

48. Hasta ahora, todo lo que he expuesto está referido a la ejecutabilidad del acuerdo obtenido en mediación en el marco de la Directiva 2008/52/CE. La razón radica en que la Directiva 2008/52/ CE guarda silencio absoluto sobre la materia del reconocimiento de los acuerdos transnacionales de mediación; lo que puede resultar llamativo, pero no debe extrañarnos, puesto que - en general- los instrumentos europeos que regulan la materia de reconocimiento y ejecución, no acostumbran a precisar las consecuencias del reconocimiento de los genéricos documentos públicos de eficacia ejecutiva y de transacciones judiciales.

49. La razón hay que encontrarla en la naturaleza negocial del acuerdo obtenido en mediación -el contenido o negotium -, que dificulta que, al albur de un régimen de reconocimiento del documento público o de la transacción judicial que lo contienen - esto es, del continente o instrumentum-, el legislador europeo alcance a alterar o innovar el derecho sustantivo que corresponda aplicar al fondo del conflicto, conforme a la ley aplicable designada por el sistema de Derecho internacional privado, que es el que ha de determinar la validez y la eficacia jurídico-material del acuerdo. Pensemos, por ejemplo, en los efectos novatorios o extintivos del acuerdo alcanzado. O en las dificultades de delimitar la eficacia de una transacción en el plano civil y, más aún, de delimitar con conceptos y criterios procesales cuál haya de ser el significado de una pretendida «eficacia de cosa transada».

50. Si esto no es razonable en el plano de la eficacia jurídico-material del acuerdo, menos justificado está que un eventual régimen de reconocimiento del acuerdo obtenido en mediación al amparo de la Directiva 2008/52/CE venga a terciar en cuestiones no menos delicadas del siempre difícil terreno de la eficacia jurídico-procesal de la cosa juzgada material, que, de entrada, hay que negar que pueda anudarse a un mero acuerdo inter partes, por más que conste o que esté homologado por una autoridad estatal con eficacia ejecutiva. En la medida en que la mediación arroja una solución pactada y no es fruto de una decisión de carácter jurisdiccional, no solo no tiene sentido plantearse la eficacia de cosa juzgada, sino que -nótese bien- hacerlo resulta sumamente nocivo. No se duda, desde luego, que la transacción despliegue eficacia vinculante entre las partes; pero de esta afirmación a aquella otra que le atribuye la eficacia propia (= la vinculación procesal) de la cosa juzgada material, hay un salto lógico enorme.

51. La confusión del plano de eficacia jurídico-material de un acto con la muy distinta eficacia jurídico-procesal en que consiste la cosa juzgada material de la sentencia firme dictada en proceso plenario (= vinculación de naturaleza procesal ad extra, de carácter positivo o prejudicial y de carácter negativo o excluyente) ${ }^{38}$, pertenece a momentos anteriores al siglo XX; tiempo en el que -dicho sea de paso- se redactó el confuso art. 1816 CC, que todavía proclama que «la transacción tiene para las partes la autoridad de la cosa juzgada; pero no procederá la vía de apremio sino tratándose del cumplimiento de la transacción judicial» (en correspondencia - valga añadir- con la eficacia ejecutiva que en su día le atribuyó el ordinal $3 .^{\circ}$ del art. 1111 de la LEC de 1855, que mezclaba promiscuamente «fuerza ejecutiva» y «fuerza de cosa juzgada»). Luego, la eficacia que atribuye el art. $1816 \mathrm{CC}$ a la transacción es, en todo caso, contractual y eventualmente ejecutiva, como tiene reconocida la Sala 1. ${ }^{a}$ del Tribunal Supremo en, entre otras, su reciente STS núm. 205/2018 de 11 de abrili ${ }^{39}$, en relación con

\footnotetext{
${ }^{38}$ Sobre la cosa juzgada civil, vid., por todos, A. De la Oliva SAntos, Sobre la cosa juzgada civil, contencioso-administrativa, y penal, con examen de la jurisprudencia del Tribunal Constitucional, Madrid, 1991 y Objeto del proceso y cosa juzgada, cit., pp. 211-228; y la más reciente aportación de I. TAPIA FERNÁNDEZ, El objeto del proceso civil y su fijación en las alegaciones, sentencia y cosa juzgada, Madrid, 2019.

${ }^{39}$ ECLI: ES:TS:2018:1238. En ella puede leerse que: «Como afirma la sentencia 751/2009, de 30 de noviembre, "la transacción extrajudicial es un contrato (art. 1809 del Código Civil; sentencias, entre otras, de 30 de octubre de 1989, 6 de noviembre de 1993 y 30 de julio de 1996), por lo que genera un vínculo obligacional cuyo cumplimiento está sujeto a las reglas generales de los contratos". En este sentido es como la jurisprudencia de esta sala ha interpretado el efecto de cosa juzgada previsto en el art. 1816 CC (...) La eficacia vinculante del acuerdo transaccional no puede confundirse con el efecto de cosa
} 
la transacción extrajudicial; y, por referencia a la transacción judicial, en su STS núm. 199/2010, de 5 de abril ${ }^{40}$.

52. Puede adivinarse que estas cuestiones no menores explican el mutismo de la Directiva 2008/52/CE acerca del «reconocimiento» de los acuerdos y documentos públicos de mediación. Pero, con todo, no alcanzan a justificar que en la Directiva 2008/52/CE no se establezca en absoluto bajo qué condiciones, p. ej., puede una parte invocar el acuerdo obtenido en mediación - con los indeterminados efectos jurídicos materiales que sean, conforme a la ley aplicable-; o desde qué momento se determina el inicio del procedimiento de mediación, al objeto, p. ej., de pedir la suspensión de un proceso judicial o la denegación de la ejecución; o, más en general, la incidencia que pueda tener en el curso de la ejecución forzosa el ejercicio en proceso declarativo de la acción de nulidad o de anulación del acuerdo obtenido en mediación y si es posible adoptar medidas cautelares o precautorias. Todas estas cuestiones, a falta de mención en el régimen armonizado de la mediación europea, quedan confiadas a la pluralidad de soluciones de cada legislación nacional, tan dispares entre sí.

\section{El caso italiano ¿como ejemplo nacional? de impulso a la mediación}

53. Dirigimos ahora la mirada al ejemplo italiano y a su Decreto Legislativo $n^{\circ} 28 / 2010$ (en adelante, d. lgs. 28/2010) ${ }^{41}$, porque, además de ser un ordenamiento culturalmente próximo al nuestro, acostumbra a presentarse como la apuesta nacional más decidida por impulsar la mediación con -como se dice ahora- «resultados verificables». Con esta ley, el legislador italiano no se ha limitado a trasponer la Directiva 2008/52/CE, sino que ha introducido dos características capaces de explicar el hecho de que, como se recoge en el Informe de 27 de junio de 2017, de la Comisión de Asuntos Jurídicos sobre la aplicación de la Directiva de mediación, en Italia se «recurre a la mediación seis veces más que el resto de Europa» ${ }^{42}$.

54. La primera peculiaridad de la norma italiana de mediación no guarda estrecha relación con la materia que nos ocupa, pero no puede dejar de apuntarse como una de las causas de éxito de la mediación italiana, pues radica en el carácter obligatorio con que el art. 5 d. lgs. 28/2010 ha impuesto - no sin algún problema de constitucionalidad ya superado- la mediación previa o anterior al ejercicio judicial de acciones en un amplísimo abanico de materias que acostumbran a presentar una alta litigiosidad (propiedad horizontal, derechos reales, sucesiones, pactos familiares, contrato de arrendamiento, comodato, resarcimiento del daño resultante de la circulación de vehículos a motor, responsabilidad médica, contrato de seguro, contratos bancarios, etc.). El legislador italiano ha configurado el intento de mediación como una condizione di procedibilità de la demanda cuya inobservancia puede ser apreciada incluso de oficio y resulta subsanable mediante la concesión, en su caso, de un plazo de quince días para la presentación de la solicitud de mediación. No es el caso de adentrarse ahora en el estudio de esta modalidad obligatoria de mediación - que presenta también una modalidad consistente en ser ordenada por

\footnotetext{
juzgada previsto en el art. 222 LEC, y no queda vedada la posibilidad de discutir en sede judicial la validez del contrato de transacción en sí mismo considerado a la luz de las normas que regulan los contratos».

${ }^{40}$ ECLI: ES:TS:2010:1874. En esta sentencia, dictada en proceso de nulidad del acuerdo transaccional aprobado judicialmente, el TS dejó claramente establecido que la eficacia de la transacción no puede identificarse con la cosa juzgada material, ni convierte en inimpugnable la transacción; el hecho de que un tribunal homologue el acuerdo transaccional no altera su esencia negocial, aunque pueda suponer la terminación anticipada del proceso al que se refiera y la atribución de eficacia ejecutiva a las eventuales obligaciones convenidas. «La homologación judicial, sin embargo, no modifica la naturaleza consensual de la transacción como negocio jurídico dirigido a la autorregulación de los intereses de las partes y, por tanto, aunque las transacciones judiciales puedan hacerse efectivas por la vía de apremio, el artículo 1817 CC no las elimina de la impugnación por vicios del consentimiento».

${ }^{41}$ Gazzetta Ufficiale, Serie Generale, n. 53 de 05.03.2010, con la advertencia de esta ley ha sufrido hasta tres modificaciones legales posteriores.

${ }^{42}$ Considerando A) de la Resolución del Parlamento Europeo de 12 de septiembre de 2017, sobre la aplicación de la Directiva 2008/52/CE, ya citada.
} 
el tribunal, incluso en fase de apelación— ${ }^{43}$, pero sí de apuntar que ésta es una tendencia que no podemos perder de vista, por los siguientes motivos.

55. Primero, porque el TJUE la ha considerado compatible con el art. 6 del Convenio Europeo de Derechos Humanos y con el art. 47 de la Carta de Derechos Fundamentales de la Unión europea. El primer paso se dio con la STJUE 18 de marzo de 2010, C-317/08, 318/08, 319/08 y 320/08, Rosalba Alassini ${ }^{44}$, que admitió la mediación de carácter obligatorio «en la medida en que tal exigencia no impide que las partes ejerzan su derecho de acceso al sistema judicial». Y el avance más reciente se encuentra en la ampliamente conocida STJUE de 14 de junio de 2017, C-75/16, Menini y Rampanelli ${ }^{45}$, dictada a propósito de la mediación en materia de consumo, donde se ha precisado que «la exigencia de un procedimiento de mediación como requisito de admisibilidad de las acciones judiciales puede ser compatible con el principio de tutela judicial efectiva cuando dicho procedimiento no conduce a una decisión vinculante para las partes, no implica un retraso sustancial a efectos del ejercicio de una acción judicial, interrumpe la prescripción de los correspondientes derechos y no ocasiona gastos u ocasiona gastos escasamente significativos para las partes, y siempre y cuando la vía electrónica no constituya el único medio de acceder a ese procedimiento de conciliación y sea posible adoptar medidas provisionales en aquellos supuestos excepcionales en que la urgencia de la situación lo exija» (aptdo. 61 de la STJUE).

56. Segundo, porque su implantación se encuentra entre las medidas recomendadas por el amplio número de expertos consultados para elaborar el estudio promovido por Dirección General de Políticas Interiores de la Unión Europea titulado Rebooting the Mediation Directive: Assessing the Limited Impact of its Implementation and Proposing Measures to Increase the Number of Mediations in the EU («Relanzamiento» de la Directiva sobre la mediación: evaluación del impacto limitado de su aplicación y propuesta de medidas destinadas a aumentar el número de mediaciones en la Unión) ${ }^{46}$, como fórmula para acabar con la llamada «UE Civil and Commercial Mediation Paradox» y elevar la prevalencia de la mediación frente al proceso judicial -ahora situada en el 1 por ciento a nivel europeo-, para lograr una relación más equilibrada entre mediación y proceso judicial.

57. Y tercero, porque en España ya se está estudiando su adopción bajo una fórmula de «obligatoriedad mitigada», consistente en obligar a las partes a celebrar ante el mediador una sesión informativa y una sesión exploratoria - que podrán celebrarse en unidad de acto-, dentro de los seis meses anteriores a la presentación de la demanda. Así se encuentra prevista en el Anteproyecto de Ley de Impulso a la Mediación aprobado en el Consejo de Ministros de 11 de enero de 2019 (art. 3 .2), que -bajo la denominación, ahora, de «Anteproyecto de medidas procesales, tecnológicas y de implantación de medios de solución de diferencias»-, acaba de superar la fase de consulta pública ${ }^{47}$. El Informe de 28 de marzo de 2019 del Consejo General del Poder Judicial - con un contudente y fundado voto particular del Excmo. Sr. D. Vicente Guilarte, al que se han adherido cuatro vocales más-48 expresa una valoración global favorable a la implantación de este «nuevo paradigma» de mediación obligatoria, desde el plano -superficial y no técnico- de la idoneidad de esta medida de política-legislativa que sigue en la agenda del Ministerio de Justicia.

${ }^{43} \mathrm{Vid}$., por todos, E. D’AlesSANDRO, "Enforcing agreements resulting from mediation within the European judicial area: a comparative overview from an italian perspective", en Barth, Böhm, Covata, ChalupKa-Dunse, Fürle, Marucci, Online-Mediation in Cross-Border Disputes, Stuttgard, 2013, pp. $89-94$ (v.e. disponible en SSRN Electronic Journal, 2011, 10, DO 10.2139/ ssrn.1950988); y C. Mandrioli y A. Carrata, Diritto processuale civile, $27^{\mathrm{a}}$ ed.,, Giappichelli, Turín, vol. III, pp. 509 y ss.

${ }^{44}$ ECLI:EU:C:2010:146.

${ }^{45}$ ECLI:EU:C:2017:457.

46 Vid. supra nota 21.

${ }^{47}$ El texto inicial del Anteproyecto puede consultarse en http://web.icam.es/bucket/Anteproyecto\%20impulso\%20 mediaci\%C3\%B3n.pdf.

${ }^{48}$ Ambos textos son accesibles en http://www.poderjudicial.es/cgpj/es/Poder-Judicial/Consejo-General-del-Poder-Judicial/Actividad-del-CGPJ/Informes/Informe-al-Anteproyecto-de-ley-de-impulso-a-la-mediacion. 
58. La segunda peculiaridad que - en los varios documentos de trabajo impulsados por la UEacostumbra a destacarse de la ley de trasposición italiana consiste en que los efectos ejecutivos del acuerdo no se hacen depender - como indica el aptdo. 1 del art. 6 de la Directiva 2008/52/CE- del hecho de que lo soliciten «ambas partes o una de ellas con el consentimiento explícito de las demás». Este es un extremo importante, aunque lo que no suele puntualizarse es que esta facilitación no es aplicable a la mediación transfronteriza objeto de la Directiva 20088/45/CE, sino únicamente a la mediación doméstica o local.

59. La fórmula acogida en Italia consiste en atribuir eficacia ejecutiva, sin más, al acuerdo de mediación doméstica o firmado por las partes con tal que estén asistidas por abogado y que los abogados también firmen el acuerdo. En estas condiciones, dice el primer párrafo del art. 12 d. lgs. 28/2010 que «l'accordo che sia stato sottoscritto dalle parti e dagli stessi avvocati costituisce titolo esecutivo (...)», lo que ofrece un perfecto ejemplo de pérdida o-cuanto menos- de aligeramiento de las garantías de autenticidad, fehaciencia y legalidad del título a las que antes aludí. Ahora bien, estas garantías sí existen en el d. lgs. 28/2010, pero están reservadas a: (i) los acuerdos de mediación en asuntos transfronterizos, que $-e x$ art. 12.1.i.f.- deben ser homologados «dal Presidente del tribunale nel cui circondario l'accordo deve avere esecuzione»; y a (ii) la conclusión de ciertos contratos susceptibles de inscripción en Registros Públicos, a los que el aptdo. 3 del art. 11 d. lgs. 28/2010 prescribe que su suscripción «deve essere autenticata da un pubblico ufficiale a cio' autorizzato», con el paradójico resultado de que el acceso registral de estos acuerdos de mediación domésticos - sin repercusiones transfronterizas- reviste, con diferencia, mayores garantías que los que se exigen para dotarles de acceso a la tutela ejecutiva.

60. ¿Quid en España? ¿Cómo hemos integrado el requisito del art. 6.1 de la Directiva 2008/54/ $\mathrm{CE}$ de que la eficacia ejecutiva se dispense «a solicitud de ambas partes o una de ellas con el consentimiento explícito de las demás»? A través del otorgamiento de la escritura específica del art. $25 \mathrm{CE}$ que, en cuanto escritura pública, tiene como contenido propio - así lo prescribe el art. 17.1.II de la Ley Notarial一 «las declaraciones de voluntad, los actos jurídicos que impliquen prestación de consentimiento, los contratos y los negocios jurídicos de todas clases» (art. 17.1.II). De la eficacia vinculante que por sí tiene el acuerdo y de la posibilidad añadida de otorgar esta escritura «al objeto de configurar su acuerdo como un título ejecutivo», debe el mediador informar a las partes a la conclusión del procedimiento de mediación (art. 23.3.II LMACM). Y es del todo aconsejable que así lo otorguen las partes, para adelantarse al surgimiento de cualquier discrepancia que rompa el clima de colaboración y que acabe con toda esperanza de reunir sobrevenidamente un consentimiento unánime para obtener la eficacia ejecutiva. No hace falta discurrir mucho para advertir que es bastante inverosímil imaginar como alternativa la interposición de una demanda de ejecución presentada por "ambas partes o [por] una con el consentimiento explícito de las demás» (que - aclarémoslo- resultaría en cualquier caso improponible por falta de título ejecutivo, de legitimación y de interés jurídico); de presentarse la demanda ejecutiva en términos semejantes, el tribunal debería denegar, sin más, el despacho de la ejecución ex art. 551.1 LEC, sin perjuicio de que las partes prefiguren ante notario el preceptivo título ejecutivo.

61. Para Esplugues Mota ${ }^{49}$, la ejecutividad del instrumento no debería hacerse depender exclusivamente de la voluntad de las partes que concluyeron el acuerdo, sino dispensarse ex lege ligada al acuerdo mismo, para favorecer que la mediación - como enuncia la propia Directiva 2008/54/CE- no se convierta en una «justicia de segunda». Pero sucede que es esta concreta voluntad de los contratantes es la que, hoy, dota de previsibilidad a la especial eficacia procesal en que consiste la ejecutabilidad del acuerdo, más allá de la obligacional que es consustancial al acuerdo mismo; $\mathrm{y}$, respecto del futuro, considero que hay que seguir confiando en los instrumentos públicos «de calidad» como llave de acceso - ex lege- a la tutela ejecutiva. No parece que interponer el otorgamiento - siempre voluntario- de escritura pública en los términos en que lo hace el art. 25 LMACM o una alternativa homologación judicial del

\footnotetext{
${ }^{49}$ En, entre otros, su "La ejecución de los acuerdos alcanzados en el marco de un procedimiento de mediación: diferentes continentes, diferentes soluciones y un objetivo - aparentemente - común”, en Revista Jurídica Digital UANDES, 3/1 (2019), 40-59, p. 43 (v.e. disponible en http://rjd.uandes.cl/index.php/rjduandes/article/view/67).
} 
acuerdo alcanzado, conviertan a la mediación en una "justicia de segunda". Entiendo, más bien, que la perspectiva con la que hay que abordar esta cuestión - que, dicho sea de paso, debe pasar también por un abaratamiento de la mediación y de los aranceles notariales ligados al otorgamiento de la escritura- es la del acceso a la tutela ejecutiva y la calidad con la que ésta se dispense, pues este es un ámbito que -por lo menos, en España- no tiene alternativas privadas de actuación y hay que cuidarlo. En particular, hay que evitar la tentación de disminuir las garantías que franquean el acceso a la ejecución y que terminan repercutiendo - siempre- en una peor calidad de la justicia ejecutiva, como muestra la historia de nuestro juicio ejecutivo o el propio proceso de ejecución italiano, que constituye un "paraíso del deudor», cuyo marco normativo -en las descriptivas palabras de una comparatista italiana- es «the ninghtmare of law students, a minefield for lawyers, and a source of endless frustration for judgement holders $\rangle^{50}$.

62. No deberíamos perder de vista que por evitar que la mediación se convierta en una «justicia de segunda», el riesgo es que terminemos convirtiendo en «justicia de segunda» el proceso de ejecución. Esto no solo lo lamentaríamos en España, sino que puede dar al traste - no lo olvidemos- con el régimen unieuropeo de circulación automática de decisiones y documentos en materia civil que se está abriendo paso en el espacio UE y que se basa en el «sello de calidad» que aporta la construcción europea del «documento público de eficacia ejecutiva».

\section{III. ¿La hora de la armonización internacional del régimen de reconocimiento y ejecución de los acuerdos de mediación transfronterizos?}

\section{El arranque de los trabajos de la CNUDMI}

63. Pues bien, siguiendo la exitosa estela de la Convención de Nueva York de 1958, que, con su ratificación por ciento cincuenta y seis Estados, constituye el marco de referencia para el reconocimiento y la ejecución de laudos arbitrales (en adelante, CNY), desde el año 2014 los EE.UU. han promovido, en el seno de la CNUDMI -y en paralelo a una modificación de la Ley Modelo de Conciliación Comercial Internacional de 2002, que ahora incluye un régimen de ejecución homólogo a la CSM-, la conclusión de un tratado multilateral que ofrece a los Estados normas uniformes sobre la ejecución de acuerdos resultantes de mediación en asuntos comerciales transfronterizos ${ }^{51}$. En homenaje a la querencia asiática por la cultura de la cooperación y la negociación frente al «paradigma adversarial» del arbitraje, el texto resultante es conocido como la «Convención de Singapur sobre la Mediación»" ${ }^{52}$, en tributo a la ciudad-Estado que ha albergado la firma de la Convención y que lleva años trabajando en esta materia -y millones invertidos en ella- para convertirse en foro de mediación de referencia internacional, sobre todo, en el eje Asia-Pacífico ${ }^{53}$.

${ }^{50}$ E. Silvestri, "The devil is in the details: remarks on Italian enforcement procedures", en C. H. Van RheE y A. UzeLac, Enforcement and Enforceability. Tradition and Reform, cit., p. 207 y passim.

${ }^{51}$ Los entresijos de la negociación de la CSM pueden verse en varios trabajos publicados por los representantes nacionales de hasta ahora-EE. UU.: T. Schnabel, "The Singapore Convention on Mediation: A Framework...", loc. cit. pp. 1-60, e "Implementation of the Singapore Convention Federalism, self-execution, and private law treaties”, en The American Review of International Arbitration, Vol. 30, pp. 265-289. Y de Australia y Singapur, respectivamente: K. McCormicK y S. S. M. ONG, "Through the looking glass: an insider's perspective into the making of the Singapore Convention on Mediation", en (2019) 31 Singapore Academy of Law Journal, special issue, v. e. disponible en https://journalsonline.academypublishing.org.sg/Journals/Singapore-Academy-of-Law-Journal-Special-Issue/Current-Issue/ctl/eFirstSALPDFJournalView/mid/503/ArticleId/1471/Citation/JournalsOnlinePDF.

La Secretaria del Grupo de Trabajo II, por su parte, ha publicado también su punto de vista en N. Y. Morris Sharma, "Constructing the Convention on Mediation. The Chairperson's perspective", en (2019) 31 Singapore Academy of Law Journal, special issue, pp. 487-519, v. e. disponible en https://journalsonline.academypublishing.org.sg/Journals/Singapore-Academy-of-Law-Journal-Special-Issue/Current-Issue/ctl/eFirstSALPDFJournalView/mid/503/ArticleId/1468/Citation/JournalsOnlinePDF.

52 Vid. el Punto 4 de la Resolución de la Asamblea General de Naciones Unidas de 20 de diciembre de 2018, ya citada.

${ }^{53}$ Sirva como botón de muestra el despliegue institucional que refieren J. HADIKUSUMO Y E. ChUA, "Recent Developments in International Mediation: Singapore's Unique Approach”, en Taipei International Conference on Arbitration and Mediation 2015, September 6-7; y G. LIM, “International commercial mediation. The Singapore model”, en (2019) 31 Singapore Academy of Law Journal, special issue, v. e. en https://journalsonline.academypublisghing.org.sg/Journals/Singapore-Academy-of-Law-Journal-Special-Issue/Current-Issue/ctl/eFirstSALPDFJournalView/mid/503/ArticleId/1465/Citation/JournalsOnlinePDF. 
64. Ahora bien, para no llevarse a engaño, digamos ya que tampoco en Singapur está arraigado el recurso a la mediación, que sigue siendo el método más impopular de resolución de controversias. Según una estadística realizada en el año 2016 por la Singapore Academy of Law entre quinientos abogados mercantilistas y operadores jurídicos del mercado asiático ${ }^{54}$, solamente un 5 por ciento de los encuestados mostró su preferencia por la mediación como método para resolver controversias, frente al 71 por cierto que se decantó por el arbitraje, seguido del 24 por ciento que lo hizo por el proceso judicial.

65. En este punto, no se oculta que los grandes usuarios de la mediación comercial en asuntos transfronterizos, esto es, las empresas y los abogados norteamericanos ${ }^{55}$, encuentran obstáculos para convencer a sus socios internacionales de solucionar sus diferencias a través de la mediación, a causa de la falta de arraigo en sus culturas de procedencia. Y se observa ${ }^{56}$ que la carencia de un régimen armonizado de eficacia extraterritorial de los acuerdos obtenidos en mediación sitúa a la mediación en franca desventaja frente al arbitraje, al que la CNY franquea la puerta del proceso de ejecución sin necesidad de intervención previa de las autoridades públicas. El resultado es que el acuerdo obtenido en mediación encuentra todavía muchas reticencias en el mundo de los negocios internacionales por la necesidad, para ganar eficacia ejecutiva, de acudir a alguna de las tres vías que acostumbran a ofrecen las diferentes legislaciones nacionales ${ }^{57}$ : (i) la homologación judicial del acuerdo, cuando la mediación se alcanza en el marco de una controversia ya judicializada; (ii) su «homologación arbitral», en el sentido de trasladar a un laudo el acuerdo alcanzado por las partes en mediación, al objeto de prefigurar su eficacia extraterritorial al amparo de la CNY, todo ello mediante variadas articulaciones híbridas de mediación y arbitraje; y (iii) la «notarización» del acuerdo, que es una modalidad presente en los sistemas de civil law como el nuestro, como se ha visto.

66. Así pues, la voluntad que alimenta la iniciativa de la CSM - que arrancó sin grandes expectativas y que ha despertado solo unas pocas adhesiones, pero ocasionalmente intensas, procedentes sobre todo del ámbito del common law ${ }^{58} 59-$ es ofrecer un régimen liberalizado de libre circulación e inmediata ejecutabilidad de los acuerdos transnacionales obtenidos en mediación, como medida deseable e idónea

${ }^{54}$ Así, S. Menon, a la sazón Chief Justice de la Supreme Court of Singapore, en su intervención titulada "The Singapore Convention on Mediation \& the coming of a New Age", pronunciada en Supreme People's Court of Vietnam workshop on mediation el día 17 de septiembre de 2019, p. 14, disponible en https://www.supremecourt.gov.sg/docs/default-source/default-document-library/vietnam-spc-mediation-workshop---for-publication.pdf; estos datos también figuran en el estudio de ChuA, E., "The Singapore convention on mediation - A Brighter Future for Asian dispute resolution", en (2019) Asian Journal of International Law, p. 10, v.e. disponible en https://doi.org/10.1017/S2044251318000309.

${ }^{55}$ T. SCHnABel, "Implementation of the Singapore Convention"..., loc. cit.., p. 289.

${ }^{56}$ Por todos, E. ChuA, "Enforcement of International Mediated Settlements without the Singapore Convention on Mediation", loc. cit, pp. 573-574.

${ }^{57} \mathrm{Vid}$. el panorama que en clave latina expone C. Esplugues MotA, en "La ejecución de los acuerdos alcanzados en el marco de un procedimiento de mediación: diferentes continentes, diferentes soluciones..”, loc. cit.; y, desde un contexto más global, E. ChuA, "Enforcement of International Mediated Settlements without the Singapore Convention on Mediation", ibidem.

${ }^{58} \mathrm{Vid}$., además de los trabajos citados en nota 48, las aportaciones de E. CHUA, "The Singapore convention on mediation - A Brighter Future for Asian dispute resolution", loc cit.,; y "Enforcement of International Mediated Settlement Agreements in Asia - A Path towards Convergence", en Asian International Arbitration Journal, vol. 15(1), pages 1-28 (2019), v.e. en https://kluwerlawonline.com/journalarticle/Asian+International+Arbitration+Journal/15.1/AIAJ2019001; de D. QUEK ANDERson, "Supporting party autonomy in the enforcement of cross-border mediates settlement agreements: A brave new world or uncharted territory?, en L. CAdiet, B. Hess y M. Requejo Isidro, Privatizing dispute resolution: Trends and limits, ed. Nomos, 2019, pp. 349-392, también disponible en https://ink.library.smu.edu.sg/sol_research/2909; de S. CHONG y F. STEFFEK, "Enforcement of International settlement agreements resulting from mediation under the Singapore Convention. Private International Law Issues in Perspective", en (2019) 31 Singapore Academy of Law Journal, special issue, v. e. disponible en https://journalsonline.academypublishing.org.sg/Journals/Singapore-Academy-of-Law-Journal-Special-Issue/Current-Issue/ ctl/eFirstSALPDFJournalView/mid/503/ArticleId/1467/Citation/JournalsOnlinePDF.

${ }^{59}$ Desde las coordenadas del civil law, la CSM ha tenido un recibimiento menos caluroso a causa de la falta de certidumbre sobre el tipo y la calidad de la mediación cuya circulación se trata de asegurar. Me he servido de las lecturas de E. SILVESTRI, "The Singapore Convention on Mediated settlement agreements: a new string to the bow of international mediation?", en Revista Eletrônica de Direito Processual, Ano 13, Volume 20, Número 2, Maio a Agosto de 2019, DOI: https://doi.org/https:// doi.org/10.12957/redp.2019.44558; y, sobre todo, por provenir de las filas de la doctrina española, del recentísimo trabajo de Esplugues Mota sobre la CSM titulado "La convención de Singapur sobre Mediación y la creación de un título deslocalizado...", loc. cit. 
para impulsar la aceptación de la mediación como medio apropiado de resolución de controversias en el plano del comercio internacional. De lo que se trata, en pocas palabras, es de contemporizar la creciente informalidad de los negocios comerciales internacionales con la del instrumento que dota de eficacia extraterritorial al acuerdo obtenido en mediación, de manera que a éste se le despoja por completo -como vamos a ver- de formalismos que entorpezcan su circulación y hasta de marco legal de referencia en el origen. Con razón se ha calificado, pues, al producto resultante de la CSM de «título deslocalizado dotado de fuerza ejecutiva directa» (Esplugues Mota), de «stateless instrument» (Schnabel, SiLVeSTRI) ${ }^{60}$.

67. Cabe indicar que, dentro de las medidas dirigidas a favorecer la firma y ratificación de la CSM - que es el punto crítico de su implantación-, se incluye un régimen bastante flexible de «reservas», regulado en el art. 8, en virtud del cual se permite, en especial, que los Estados se reserven la posibilidad de otorgar a los contratantes una suerte de opt in, de modo que puedan acogerse al CSM «solo en la medida en que las partes en el acuerdo de transacción hayan consentido que se aplique» (art. 8.1.b), lo que abre las puertas de la CSM - ya suficientemente amplias- a contratos que de otra manera no las tendrían abiertas, como, p. ej., los acuerdos de mediación domésticos. Por su parte, el art. 7 CSM recoge la llamada «regla de la máxima eficacia», por la que la CSM renuncia a su aplicación preferente frente a otros regímenes, nacionales o convencionales, que puedan dispensar eficacia ejecutiva extraterritorial más fácilmente, si así lo desean las partes.

\section{El ámbito de aplicación de la CSM}

68. El art. 1 CSM regula el Ámbito de aplicación de este instrumento mediante el establecimiento, de un lado, de los requisitos que -en sentido positivo- debe reunir el acuerdo obtenido en mediación para ser objeto de la CSM (aptdo. 1) y, de otro lado, mediante la determinación -en sentido negativode los acuerdos que quedan excluidos de la CSM en razón de la materia o del procedimiento de resolución seguido. El resultado que arroje la conjunción de estos criterios cabe considerarlo el «título ejecutivo» al que la CSM asegura la libre circulación internacional, pese a que prescinde de emplear la idea noción de «instrumento ejecutable» o de «título ejecutivo», que queda así confundido con el contenido o negotium.

\section{A) El acuerdo escrito firmado por las partes obtenido en mediación con el fin de resolver una con- troversia comercial internacional}

69. El aptdo. 1 del art. 1 CSM delimita positivamente a qué clase de acuerdos se aplica el régimen de circulación que se propone: al «acuerdo escrito» «firmado por las partes» que haya sido «obtenido en mediación» con el fin de resolver una «controversia internacional comercial». Veamos, con distinto orden, en qué ha de consistir cada uno de estos elementos que constituyen el presupuesto de aplicabilidad de la CSM, con la advertencia de que la CSM está implícitamente al servicio de la Ley Modelo de la CNUDMI sobre Mediación Comercial Internacional y Acuerdos de Transacción Internacionales Resultantes de la Mediación, de 2018, a cuyo texto hay que acudir para terminar de perfilar algunos de sus conceptos.

\section{a) Acuerdo obtenido en mediación}

70. La CSM circunscribe su aplicación, en primer término, al acuerdo «resultante de la media-

\footnotetext{
${ }^{60}$ C. Esplugues Mota, "La Convención de Singapur de 2018 sobre mediación y la creación de un título deslocalizado...", loc. cit., p. 57; T. Schnabel, "The Singapore Convention on Mediation: A Framework...”, loc. cit., p. 22; y E. SiLveSTRI, "The Singapore Convention on Mediated settlement agreements...", loc. cit., p. 193.
} 
ción» en los términos que el aptdo. 3 del art. 2 se encarga de definir: «se entenderá por "mediación", cualquiera sea la expresión utilizada o la razón por la que se haya entablado, un procedimiento mediante el cual las partes traten de llegar a un arreglo amistoso de su controversia con la asistencia de uno o más terceros ("el mediador") que carezcan de autoridad para imponerles una solución».

71. Lo definitorio de la mediación de la CSM no es, pues, la denominación que se emplee para aludir a ella, sino la intervención de carácter no dirimente del tercero llamado «mediador». La ausencia, al tiempo de alcanzarse el acuerdo, de potestades para resolver el conflicto por parte del tercero o mediador es lo que caracteriza la mediación y preserva su naturaleza autocompositiva de solución de controversias. Pero una delimitación ulterior del «acuerdo mediado» que es objeto de la CSM pasa por efectuar cuatro observaciones.

72. La primera es terminológica, para advertir que la CSM ha terminado acogiendo los términos «mediación» y «mediador», en lugar de «conciliación» y «conciliador», por - se dice- mera actualización lingüística, ya que los primeros tienen un uso más generalizado en la actualidad. Lo mismo se ha hecho en la Ley Modelo, que ha tenido algunos ajustes «con la expectativa de que el cambio facilite la promoción de la Ley Modelo y aumente su visibilidad $\rangle^{61}$. Queda, así, avisado el lector de que los términos «conciliación» y «mediación» son intercambiables en la CSM. Sin embargo, resulta perturbador que el texto también aparezca salpicado, aquí y allá, del concepto de «contrato de transacción», que bien podría haberse sustituido por los anteriores, si es que se tienen -como se dice- por completamente intercambiables. La razón de que no se haya hecho se encuentra fuera de la CSM; concretamente, está situada en el hecho de que lo que la Ley Modelo considera intercambiables y equivalentes, de acuerdo con su art. 1.1, son los conceptos de «mediación comercial» y «acuerdos de transacción» internacionales. El resultado es un puzzle al que le falta armonía interna y que, con razón, se ha hecho acreedor de la crítica de amontonar conceptos diferentes sin precisión que le dedica EsPluges MотA ${ }^{62}$. La cuestión dista de ser meramente lingüística, porque, sin un marco legal de referencia aplicable al acuerdo obtenido en mediación, su objeto es, en principio, omnicomprensivo: abraza toda suerte de transacciones, acuerdos, negociaciones y cualquier producto jurídico que arroje la mediación.

73. La segunda observación tiene más enjundia, por varias circunstancias. Para la CSM da lo mismo la razón por la que se haya acudido a la mediación. Como tributo al art. 6.3 de la Ley Modelo, poco importa - como se ha observado ${ }^{63}$ - que hayan llegado las partes por iniciativa propia o por disposición de un tribunal o de otra autoridad. También resulta irrelevante que a la mediación hayan acudido las partes antes o después del surgimiento de las diferencias ${ }^{64}$. Lo decisivo - nótese bien- es que el acuerdo sea el producto amistoso de un indeterminado procedimiento en cuya conclusión haya intervenido un mediador. Ni siquiera se precisa - a diferencia del art. 3.a) de la Directiva 2008/52/CE- que el procedimiento revista cierta «estructuración», como admite el propio SCHNABEL sin ocultar la preocupación de las delegaciones alemana, austriaca y de la UE durante la negociación del texto ${ }^{65}$. Y, en fin, la CSM no prefigura tampoco la clase, el contenido, la intensidad o la duración de la «asistencia» del mediador. El mismo SCHNABeL propone que el art. 1.1 CSM no es incompatible con que las partes convengan en convertir al mediador en árbitro, sin que ello desborde el ámbito de la CSM, puesto que al tiempo del "acuerdo de cambio de ADR" se cumpliría el requisito de que al mediador le falte la facultad para dirimir el conflicto ${ }^{66}$.

74. La tercera precisión es que la eficacia ejecutiva está vinculada ex lege al acuerdo mismo

\footnotetext{
${ }^{61}$ Nota 1 de pie de página la Ley Modelo de Mediación Comercial Internacional y Acuerdos de Transacción Internacionales Resultantes de la Mediación, de 2018, introducida por el grupo de trabajo.

62 Vid. supra nota 4.

${ }^{63}$ Así, T. Schnabel, “The Singapore Convention on Mediation: A Framework...”, loc. cit. pp. 16-17; y C. Esplugues Mota, "La convención de Singapur sobre Mediación y la creación de un título deslocalizado...", loc. cit., p. 62.

${ }^{64} \mathrm{Vid}$. T. Schnabel, "The Singapore Convention on Mediation: A Framework...,", loc. cit. pp. 15-16.

${ }^{65}$ T. SchnABel, "The Singapore Convention on Mediation: A Framework...", loc. cit. pp. 15-16 y notas 84 y 87.

${ }^{66}$ Vid. T. Schnabel, "The Singapore Convention on Mediation: A Framework...", loc. cit. p. 17.
} 
obtenido en mediación -siempre que reúna, se entiende, el resto de requisitos del art. 1 CSM-, sin que se exija ninguna clase de «enforceable clause» o constancia de la voluntad de todas las partes de dotar de eficacia ejecutiva al acuerdo obtenido en mediación. De este sistema, que es el que rige - por ahoraen la UE en virtud del art. 6 de la Directiva 2008/52/CE, prescinde por completo la CSM, de tal manera que toda clase de obligaciones asumidas en el acuerdo obtenido en mediación tendrá, además de la consustancial eficacia contractual, una también consustancial eficacia ejecutiva a la que genéricamente se refiere el art. 4 CSM y que el art. 3.1 manda hacer efectiva a cada Estado parte «de conformidad con sus normas procesales y en las condiciones establecidas en la presente Convención». Ni siquiera se circunscribe la eficacia automática del acuerdo mediado a las obligaciones de naturaleza dineraria, como sugirió la Unión Europea durante las negociaciones, sin éxito ${ }^{67}$. Este texto propone, en suma, ilimitada ejecutividad inmediata del acuerdo, sin términos intermedios.

75. Quiere decirse que, a la postre, la eficacia extraterritorial del acuerdo gravita alrededor de la intervención final del mediador, que no aparece revestido de ninguna garantía en la CSM, aunque es verdad que tampoco le han sido dadas facultades para imponer la solución a las partes. De esta forma, la CSM ha creado -no sin polémica durante las negociaciones- «a new category of legal instrument on the internacional plane (...) a new status to mediated settlements» (SCHNABEL) ${ }^{68}$, dotado de una especial eficacia extraterritorial solo por la circunstancia de ser el producto de una mediación comercial transnacional ${ }^{69}$. O en pocas palabras: la CSM ha convertido al mediador en el «alquimista» capaz de transmutar un acuerdo privado en un título ejecutivo de eficacia transfronteriza gracias a la «piedra filosofal» de la mediación, que obra el prodigio de convertir los metales en oro. Aquí radica, en mi opinión, el meollo de la cuestión y el dilema que tiene ante sí, en particular, la UE, en cuyo espacio judicial civil de confianza mutua entre los Estados miembros no se ha llegado tan lejos como propone este texto con aspiración planetaria.

76. La cuarta precisión no consuela de los defectos anteriores, sino que los acrecienta. Guarda relación con la pretensión de algunas delegaciones - México y China, fundamentalmente- de incluir en el ámbito de la CSM, junto a los acuerdos "mediados", los contratos privados de carácter comercial internacional, sin más requisitos. Pues bien, esta pretensión se rechazó de forma expresa durante las negociaciones, pero $\mathrm{SCHNABEL}^{70}$ ha propuesto una vía que podría conducir al mismo resultado práctico, al amparo -dice- de la posibilidad de extender la Convención a tales contratos, en virtud de las amplias previsiones del art. 7 CSM. Esta opinión - puede pensarse- no pasa de ser una interpretación más de la CSM. Y así es; exactamente como todas. Pero la influencia de la persona que la propone favorece que pueda tener acogida una lectura exacerbada del art. 1.1 CSM que pueda acabar suponiendo que la CSM se emplee desnaturalizadamente como medio para concluir negocios comerciales internacionales de eficacia extraterritorial inmediata, y no para «dirimir una controversia comercial», como pide el art. 1.1 CSM y se reitera en el art. 2.3 CSM, en el bien entendido de presuponerse -aunque no se diga de forma expresa- la preexistencia de la relación comercial misma. En mi opinión, es rechazable una lectura tal que desfigure la quintaesencia de la mediación como método de resolución de conflictos alternativa al proceso jurisdiccional. Considero que, siendo - por supuesto- lícito el fomento del comercio internacional, hay que poner en evidencia que una convención dedicada al régimen del reconocimiento y la ejecución internacionales de ciertos acuerdos privados no es razonable que acabe convertida en el instrumento que permita concluirlos, borrando de un plumazo todo marco legal de referencia para sustituirlo por la autorreferencialidad de la propia CSM, que es, a la postre, la de la libérrima voluntad de los contratantes.

77. La - sólo en apariencia- contrapartida a la laxitud con la se define el acuerdo resultante de mediación objeto de la CSM radica en que, para hacer valer la eficacia del acuerdo resultante de la

\footnotetext{
${ }^{67}$ Vid. T. SchnABEL, "The Singapore Convention on Mediation: A Framework...", loc. cit. pp. 11-12.

${ }^{68} \mathrm{Vid}$. T. Schnabel, "The Singapore Convention on Mediation: A Framework...", loc. cit. pp. 9-11.

${ }^{69} \mathrm{Vid}$. las críticas de C. Esplugues Mota, "La convención de Singapur sobre Mediación y la creación de un título deslocalizado...", loc. cit., pp. 64-66.

${ }^{70}$ T. Schnabel, “The Singapore Convention on Mediation: A Framework...”, loc. cit. p. 19.
} 
mediación, es preciso aportar la prueba de que ha sido obtenido a través de la mediación, además de tener que aportarse el propio acuerdo firmado por las partes. En este sentido, el aptdo. 1 del art. 4 CSM exige que se aporten «pruebas de que se llegó al acuerdo de transacción como resultado de la mediación, por ejemplo: i) La firma del mediador en el acuerdo de transacción; ii) Un documento firmado por el mediador en el que se indique que se realizó la mediación; iii) Un certificado expedido por la institución que administró la mediación; o iv) A falta de las pruebas indicadas en los incisos i), ii) o iii), cualquier otra prueba que la autoridad competente considere aceptable». Ahora bien, la exigencia de esta aportación está muy descafeinada, puesto que la sola firma del mediador estampada en el acuerdo o, en su defecto, la aportación de un certificado del centro de mediación colman, por sí mismas, la prueba de haberse obtenido el acuerdo como resultado de haberse seguido un procedimiento de mediación, lo que, en ausencia de reglas de estándares mínimos sobre la calidad de la mediación o la formación del mediador -cuya cualidad de independiente y la obtención de algún tipo de cualificación se rechazaron durante las negociaciones de la $\mathrm{CSM}^{71}$ - convierte a esta firma o al certificado en un bien extremadamente valioso para conseguir la circulación internacional del acuerdo, sin exigencias jurídicas a cambio relativas siquiera a la autenticidad o la fehaciencia del documento.

78. Además, a las autoridades de ejecución no les ha sido dada incondicionalmente la potestad de recabar otras pruebas que acrediten la existencia del procedimiento de mediación, pues esta potestad solo se tiene de forma subsidiaria, de acuerdo con lo que dispone el art. 4.1.b.iv) CSM, cuando el acuerdo mediado no figura firmado por el mediador y la parte contratante, ni tampoco el solicitante ha aportado certificado del mediador o del centro de mediación; lo que confiere un carácter limitado a la amplitud con la que parece operar el art. 4.4 CSM, en virtud del cual la autoridad del Estado de ejecución puede «exigir cualquier documento que sea necesario para verificar que se han cumplido los requisitos establecidos en la Convención». Lo puede pedir, sí, pero solo cuando el acuerdo no vaya firmado por el mediador, ni el solicitante se haya aportado alguno de los mencionados certificados del mediador o del centro.

\section{b) Exigencia de la forma escrita y de la firma del acuerdo. Idioma y traducción}

79. Para poder disfrutar del régimen de eficacia extraterritorial inmediata que ofrece la CSM a los acuerdos de mediación que constituyen su objeto, basta con que el acuerdo revista forma escrita. $\mathrm{El}$ art. 2.2 CSM proporciona la definición de la forma escrita requerida por el art. 1.1 CSM, que queda rebajada a que quede constancia duradera del acuerdo de cualquier forma: «Se entenderá que un acuerdo de transacción se ha celebrado "por escrito" si ha quedado constancia de su contenido de alguna forma. El requisito de que el acuerdo de transacción conste por escrito se cumplirá con una comunicación electrónica si es posible acceder a la información contenida en ella para su ulterior consulta».

80. En este art. 2.2 CSM quedan retratados el antiformalismo y la flexibilidad que se predican como virtudes de la mediación y que no lo son tanto cuando se aplican no ya a la materia del comercio internacional, sino a la que constituye el régimen de reconocimiento y ejecución que aspira a infundir confianza en la mediación a todos los operadores jurídicos, y no solo a las partes favorecidas por los benéficos efectos de la eficacia extraterritorial que se trata de dispensar. A los efectos de lograr su circulación internacional, basta con que del acuerdo alcanzado quede constancia o bien «por escrito», incluida su constancia electrónica siempre que sea posible su almacenamiento y recuperación posterior para consulta, o bien de cualquier otra manera. Esto es: una constancia que vive al margen de todo formalismo, pero también al margen de las garantías que representan el otorgamiento de documento público o la aprobación del acuerdo por una autoridad, respecto de la autenticidad del documento, la legalidad del acuerdo y la identidad y capacidad de las personas que intervienen en él. No es de extrañar que a algunos juristas con mentalidad continental pueda darnos escalofríos pensar que el mero documento privado "intervenido por mediador" que documente un acuerdo comercial internacional constituya una

${ }^{71}$ Vid. T. SchnABEL, "The Singapore Convention on Mediation: A Framework...", ibidem. 
clase nueva de instrumento jurídico en razón de su cualificada eficacia extraterritorial, en el que se han perdido los confines entre el negotium y el instrumentum.

81. Por otro lado, el acuerdo mediado ha de contar con la firma, al menos, de todas las partes; como se ha visto, la del mediador puede suplirse en los términos - ya mencionados- de la letra b) del art. 4.1 CSM. En este punto, el aptdo. 2 del art. 4 facilita la firma electrónica del acuerdo en los siguientes términos: «el requisito de que el acuerdo de transacción esté firmado por las partes o, cuando corresponda, por el mediador, se dará por cumplido respecto de una comunicación electrónica: a) Si se utiliza un método para determinar la identidad de las partes o del mediador y para indicar la intención que tienen las partes o el mediador respecto de la información contenida en la comunicación electrónica; y b) Si el método empleado: i) O bien es tan fiable como sea apropiado para los fines para los que se generó o transmitió la comunicación electrónica, atendidas todas las circunstancias del caso, incluido cualquier acuerdo que sea pertinente; o ii) Se ha demostrado en la práctica que, por sí solo o con el respaldo de otras pruebas, dicho método ha cumplido las funciones enunciadas en el apartado a) supra».

82. El idioma del acuerdo de mediación -o los varios que hayan podido emplearse- puede ser cualquiera que las partes acepten. La única previsión de la CSM sobre este extremo consiste en disponer que cuando se haga valer el acuerdo redactado en un idioma distinto del oficial del Estado del foro, puede el tribunal «pedir una traducción del acuerdo a ese idioma» (art. 4.3 CSM).

\section{c) Carácter internacional y comercial del acuerdo obtenido. La «deslocalización» del acuerdo}

83. El atributo de la «internacionalidad» del acuerdo de mediación objeto de la CSM gira en torno al lugar del «establecimiento» de las partes o, en su defecto, de la concurrencia un vínculo de conexión con el territorio de otro Estado. En concreto, de acuerdo con el aptdo. 1 del art. 1 CSM (homólogo del art. 3.2 de la Ley Modelo), la internacionalidad se determina al tiempo de concluirse el acuerdo - esto es, sobrevenidamente-, y a causa de concurrir alguna de estas dos circunstancias: (i) que «al menos, dos» de las partes contratantes tengan «sus establecimientos en Estados diferentes», en el bien entendido que, de acuerdo con la definición de «establecimiento» del art. 2.1 CSM, «cuando una parte tenga más de un establecimiento, prevalecerá el que guarde una relación más estrecha con la controversia dirimida mediante el acuerdo de transacción, considerando las circunstancias conocidas o previstas por las partes en el momento de celebrar el acuerdo», y que «cuando una parte no tenga ningún establecimiento, se tendrá en cuenta su lugar de residencia habitual»; o bien (ii) que el Estado del «establecimiento» de las partes - con aplicación de los criterios mencionados- sea distinto de aquel donde deba cumplirse «una parte sustancial de las obligaciones derivadas del acuerdo», o bien no sea el Estado «que está más estrechamente vinculado al objeto del acuerdo».

84. La CSM se aplica, desde este punto de vista, a todo acuerdo comercial de carácter o alcance internacional, con independencia del lugar donde se haya desarrollado la mediación o del lugar donde se ubique el mediador o el centro de mediación. El desarrollo de las comunicaciones telemáticas convierte en irrelevante el lugar de la negociación del acuerdo, para poner el foco en el lugar del negocio sobre el que versa el acuerdo, lo que plantea, al menos, dos observaciones.

85. La primera, en importancia menor, es que la CSM no proporciona ninguna definición de «establecimiento» o «place of bussiness», en el que descansa, en primera instancia, la clave de la internacionalidad que se pide para su aplicación. Aunque se ha propuesto acudir «a otros textos elaborados por la CNUDMI» ${ }^{72}$, parece que el término está empleado en sentido material.

\footnotetext{
${ }^{72}$ C. Esplugues Mota, "La convención de Singapur sobre Mediación y la creación de un título deslocalizado...", loc. cit., p. 62 .
} 
86. La segunda observación radica en que en la CSM el acuerdo de mediación no tiene nacionalidad, ni la mediación, sede. Estas nociones, tan necesarias cuando se trata de dotar de eficacia extraterritorial a resoluciones judiciales y a laudos, han sido deliberadamente excluidas de la Convención. El acuerdo resultante de la mediación que es objeto de la CSM o es internacional o no lo es -como se ha postulado, según hemos visto-, pero no es del "Estado X" o del "Estado Y": en su circulación internacional no hay binomio "Estado de origen" y "Estado requerido", razón por la que se dice que la Convención - al decir de EsPluges Mota- «diseña un título esencialmente desvinculado de cualquier ordenamiento jurídico de referencia» ${ }^{73}$.

87. El estudio de las consecuencias que pueda tener esta caracterización del acuerdo de mediación corresponde a iusprivatistas y a internacionalistas. Desde la perspectiva del Derecho procesal, hemos de limitarnos a observar que esta deslocalización propicia que, con ocasión de regular el "reconocimiento" o a la ejecución del acuerdo, se introduzcan determinaciones legales ajenas al tratamiento procesal de la cuestión. Es posible ilustrarlo con dos ejemplos y medio. Al albur de disposiciones en apariencia procesales, la CSM deja prefiguradas, en concreto: (i) la total o parcial eficacia -que tendrá que ser valorada ad casum-del carácter excluyente o enervatorio - parece, puesto que no es apreciable de oficio- que el aptdo. 2 del art. 3 CSM atribuye al acuerdo obtenido en mediación, respecto de hechos jurídicos producidos con anterioridad a la conclusión del acuerdo, pues no otra cosa significa que se permita a la parte invocar la existencia del acuerdo «a fin de demostrar que la cuestión ya ha sido resuelta»; y (ii) con ocasión del motivo de oposición a la ejecución que alegue el ejecutado para suscitar la ineficacia o invalidez del acuerdo al amparo de la letra b) del art. 5.1 CSM, la CSM deja determinado que la ley aplicable al fondo de esta cuestión será «la ley a la que las partes lo hayan sometido válidamente o, si esta no se indicara en él, a la ley que considere aplicable la autoridad competente de la Parte en la Convención en que se soliciten medidas». A mitad de camino se encuentra la salvaguarda del orden público del Estado del foro, que, conforme al aptdo. 2 del art. 5 CSM, no solo sirve para preservar los postulados fundamentales de su ordenamiento, sino también para controlar el carácter dispositivo del objeto de la controversia y los términos en que puede «resolverse por la vía de la mediación».

88. Por su parte, art. 1.1 CSM también pide que el acuerdo obtenido en mediación presente carácter «comercial», pero no ofrece una definición legal de este atributo al que termina de dar forma la relación de las materias y asuntos que quedan extramuros del Convenio en virtud de las exclusiones del aptdo. 2 del art. 1. SchnABel propone como ejemplos de carácter mercantil los contratos de inversión estatal relativos al sector de la construcción o a la extracción de fuentes naturales ${ }^{74}$; y SiM, los que ponen fin a los conflictos entre inversionistas y Estados ${ }^{75}$.

\section{B) Materias excluidas de la CSM}

89. El aptdo. 2 del art. 1 CSM contiene las exclusiones del ámbito del Convenio, ya en razón del carácter no comercial de la materia, ya en razón de la existencia de otros instrumentos internacionales que ya regulan su reconocimiento y ejecución en el plano internacional. El abanico de materias comprende: (i) los acuerdos obtenidos en materia de consumo, caracterizados como aquellos «en $\mathrm{l}[\mathrm{o}] \mathrm{s}$ que una de las partes (un consumidor) participe con fines personales, familiares o domésticos»; (ii) los «relacionados con el derecho de familia, el derecho de sucesiones o el derecho laboral»; (iii) los acuerdos «que hayan sido aprobados por un órgano judicial o concertados en el curso de un proceso ante

${ }^{73}$ C. Esplugues Mota, "La convención de Singapur sobre Mediación y la creación de un título deslocalizado...", loc. cit., p. 63.

${ }^{74}$ T. Schnabel, "The Singapore Convention on Mediation: A Framework...", loc. cit., pp. 22-23.

75 Vid. C. Sim, "Conciliation of Investor-State Disputes Arb-Con-Arb and the Singapore Convention", Singapore Academy of Law Journal, 31(Special Issue), 670-712, espec. 691 y ss, v. e. disponible en https://journalsonline.academypublishing. org.sg/Journals/Singapore-Academy-of-Law-Journal-Special-Issue/Current-Issue/ctl/eFirstSALPDFJournalView/mid/503/ArticleId/1475/Citation/JournalsOnlinePDF. 
un órgano judicial» y sean susceptibles de «ejecutarse como una sentencia en el Estado de ese órgano judicial», es decir, entre otros, nuestras unieuropeas «transacciones judiciales que tengan fuerza ejecutiva en el Estado miembro de origen» a que se refiere - entre otros- el art. 59 del Reglamento 1215/2012, materia cuya exclusión fue una exigencia de la UE durante las negociaciones de la CSM para preservar la normal circulación intraeuropea de estos títulos ${ }^{76}$; y (iv) los acuerdos de las partes «que hayan sido incorporados a un laudo arbitral y sean ejecutables como tal».

\section{IV. ¿En qué consiste la «eficacia extraterritorial» que atribuye la convención?}

90. La CSM se aleja de la tradicional distinción entre «reconocimiento» y «ejecución» del acuerdo de mediación y, en su lugar, los define funcionalmente en el art. 3 CSM. Este artículo contempla - cabe decir que naturalísticamente- las dos «utilidades» procesales que cabe dar al acuerdo obtenido en mediación y que se corresponden, materialmente, con la línea que distingue entre el «reconocimiento» y la «ejecución» de resoluciones, acuerdos y documentos, a saber: (i) invocarlo «como defensa», con la indeterminada eficacia que deba tener en el plano sustantivo, para basar en él hechos impeditivos, extintivos o excluyentes que puedan asociarse al hecho de «que la cuestión ya ha sido resuelta», que es el plano que se corresponde con el tradicional «reconocimiento»; y (ii) pedir la ejecución del acuerdo, empleándolo «como un arma» ante el incumplimiento de la contraparte, para que por las autoridades competentes se adopten las medidas ejecutivas que resulten precisas para realizar la responsabilidad que se deriva del incumplimiento del acuerdo, que es el plano en el que opera la «eficacia ejecutiva».

\section{La «which-is-no-called-"recognition"» del acuerdo obtenido en mediación}

91. Omni definitio in iure civile periculosa est, pensaron los negociadores de la CSM cuando se enfrentaron a la tarea de definir o dar forma al «reconocimiento» del acuerdo obtenido en mediación ${ }^{77}$, siguiendo una tendencia que también se advierte en el ámbito unieuropeo. En el caso de la CSM, se trata de una omisión deliberada - sugerida por la delegación israelí durante las negociaciones, mediante a una solución de compromiso, ante la oposición de la UE a que la materia fuera objeto de la Convención ${ }^{78}$ que orilla el problema que habría supuesto definir con precisión qué alcance habría entonces que dar a la eficacia de «cosa transada» como usual consecuencia del reconocimiento.

92. No encontramos, así, ninguna alusión al «reconocimiento»-salvo en el art. 12.4 CSM, para, eventualmente, dejar a salvo sistemas jurídicos integrados como el unieuropeo- y esta carencia se suple con una descripción funcional del "núcleo duro" de los efectos del reconocimiento que importa preservar con todo sentido práctico. El resultado de «which-is-no-called-"recognition"”-SCHNABEL dixit"es el aptdo. 2 del art. 3 CSM, a cuyo tenor «si surgiera una controversia acerca de una cuestión que una parte alegue que ya ha sido resuelta mediante un acuerdo de transacción, la Parte en la Convención deberá permitir a la parte invocar el acuerdo de transacción de conformidad con sus normas procesales y en las condiciones establecidas en la presente Convención, a fin de demostrar que la cuestión ya ha sido resuelta».

93. La ausencia formal de un mecanismo depurado de «reconocimiento» no perjudica lo funcionalmente importante aquí, en mi opinión. Lo decisivo del reconocimiento es que la eficacia vinculante que genera el acuerdo de mediación y los efectos constitutivos, modificativos o excluyentes de los de-

\footnotetext{
${ }^{76}$ Vid. T. Schnabel, "The Singapore Convention on Mediation: A Framework...", loc. cit., pp. 24-25.

77 Vid. T. Schnabel, "The Singapore Convention on Mediation: A Framework...,", loc. cit., p. 37.

${ }^{78}$ Las razones de la oposición de la UE pueden verse en T. Schnabel, "The Singapore Convention on Mediation: A Framework...", loc. cit. p. 35

79 Vid. T. Schnabel, "The Singapore Convention on Mediation: A Framework...", loc. cit. p. 7.
} 
rechos y obligaciones que las partes hayan decidido asumir en el acuerdo - esto es, en suma, la eficacia jurídica que despliegue éste en el plano sustantivo o material-, puedan alegarse o invocarse ante las autoridades del Estado del foro, donde quiere el demandante que se tenga en cuenta y se honre el acuerdo obtenido en mediación. Y en este punto, la CSM, huyendo de construcciones dogmáticas complejas -pero de beneficiosa existencia-, se limita a garantizar que así sea, imponiendo a los Estados parte que su legislación interna permita «invocar el acuerdo» «en las condiciones establecidas en la Convención», «para demostrar que la cuestión ya ha sido resuelta».

94. ¿Significa lo anterior que la CSM propicia la existencia de una pretendida «eficacia de cosa transada»? La respuesta es sí, sin lugar a dudas, aunque durante las negociaciones el adjetivo del inciso final lo ocupó el término «mediada» que luego fue sustituido por «resuelta» ${ }^{80}$. La cuestión es otra. Lo importante es definir en qué consista esta eficacia y qué utilidad tiene, se la llame como se la llame. Si la pregunta es si la eficacia de «cosa transada» es la misma que la eficacia de «cosa juzgada material», a esta cuestión hay que responder desde el Derecho procesal con un sonoro «no». Es un oxímoron afirmar que la CSM dota al acuerdo mediado de eficacia de cosa juzgada «de facto» ${ }^{81}$, borrando de un plumazo siglos de evolución jurídica en muchos países de civil law; y si esto fuera lo pretendido, constituye -desde luego- una razón para la crítica de la CSM.

95. No puedo detenerme a desarrollar ideas complejas aquí y ahora, pero permítaseme señalar que entre una y otra «cosa» - la «transada» y la «juzgada»- existen estas profundas diferencias que no solo obedecen al consustancial cambio de prisma: (i) de objeto o ámbito, pues la «transada» se debe predicar de todo acuerdo respecto de lo que constituya su objeto, mientras que la «juzgada» debemos seguir reservándola para lo decidido jurisdiccionalmente, porque a ello se anudan sus cualificadas consecuencias; (ii) su destinatario último, puesto que la cosa «transada», como obligacional que es, tiene por destinatarios a las partes contratantes, mientras que la cosa «juzgada» tiene por sujeto destinatario al tribunal ante el que se plantee un proceso idéntico -en cuyo caso operará la eficacia negativa o excluyente- o un proceso conexo - en cuyo caso lo hará la positiva o prejudicial-, sin perjuicio -claro estáde la valoración que el resto de sujetos pueda darle a cada «cosa» como hechos dotados de eficacia - sin más-jurídica («transada» el uno, «juzgada» el otro); y (iii) por la naturaleza de sus consecuencias, pues mientras que la cosa «transada» no desborda la naturaleza contractual y contiene sus efectos en obligar a los contratantes a respetar lo transado, que es -nótese bien- lo que justamente facilita el art. 3.2 CSM sin obligar al tribunal de ejecución en un sentido determinado más allá del deber de pronunciarse sobre el fondo de esta cuestión con libertad enjuiciadora, en cambio la esencia -de naturaleza procesal- de la «cosa juzgada» siempre y de forma necesaria despliega su eficacia consistente en obligar a un juez a limitar su cognición en la doble dirección de excluir la existencia de un segundo proceso idéntico al primero - cuando opera la eficacia negativa o excluyente- o de quedar obligado a tomar lo ya juzgado en el mismo sentido en que se juzgó - cuando opera la eficacia positiva o prejudicial-. Esto -añadono se acierta a identificar en el art. 3.2 CSM, a causa, precisamente, de lo muy controvertido que puede resultar atribuir una eficacia de semejante entidad al mero acuerdo privado mediado, por no mencionar la devaluación que, especularmente, se infligiría a un concepto tan preciso y necesario para la seguridad jurídica como la cosa juzgada material, siquiera cuando todo ello quedara circunscrito a una suerte de nuevo sistema de justicia convencional en el ámbito del comercio internacional.

96. Tampoco puede pasarse por alto que la noción misma de «cosa transada» resulta todavía más etérea e imprecisa en el contexto de la CSM, en ausencia de vínculos que relacionen el acuerdo obtenido en mediación con un ordenamiento de referencia como Estado "de origen". Adviértase que no existe un parámetro que pueda predeterminar la validez y la eficacia de lo convenido en la mediación que es objeto de la CSM; aunque, paradójicamente, el texto de Singapur garantiza su efectividad allí donde quiera que sea necesario o conveniente que el acuerdo transado sea reconocido y despliegue su eficacia.

\footnotetext{
${ }^{80}$ Vid. T. Schnabel, "The Singapore Convention on Mediation: A Framework...", loc. cit. p. 41.

${ }^{81}$ C. Esplugues Mota, “La convención de Singapur sobre Mediación y la creación de un título deslocalizado...”, loc. cit., p. 68.
} 
97. Por lo demás, el carácter indeterminado de la eficacia jurídica del contenido del acuerdo explica la también genérica naturaleza de las «medidas» que podrá solicitar la parte contratante -art. 4.1 CSM - cuando invoque la existencia del acuerdo resultante de la mediación comercial transnacional con fines distintos de los ejecutivos, que es asunto que se aborda inmediatamente después. Todavía en el plano del "reconocimiento" de efectos, Esplugues Mota se ha quejado - con razón de nuevo- de que la expresión «otorgar medidas» es «desconocida, vaga e indescifrable en nuestro ordenamiento ${ }^{82}$. Y, en efecto, así es. Podría pensarse que entre las medidas no ejecutivas o de «ejecución impropia» que se pueden acordar en España para que los acuerdos que nos ocupan puedan desplegar la plenitud de su eficacia jurídica se incluyen -al menos, teóricamente- su inscripción en Registros públicos y el resto de actuaciones complementarias que dan lugar a la llamada «ejecución impropia» a que se refieren los arts. 521 y 522 LEC. Sin embargo, son conocidos los obstáculos que la legislación registral pone, desde luego, al acceso al Registro de simples documentos privados que no son funcionalmente equivalentes a los públicos que permiten causar inscripciones. Si este acceso -desde la Resolución de la DGRN de 25 de febrero de 2014 hasta la actualidad- le está vedado a los acuerdos transaccionales que han sido homologados judicialmente y a los convenidos en conciliación, a los que se les exige su elevación a escritura pública notarial ${ }^{83}$, no parece aceptable que se dispense mejor trato al documento privado de un acuerdo «apátrida» obtenido en mediación comercial transnacional. Y si lo que se pretende no son inscripciones registrales, sino, p. ej., la puesta en conocimiento de terceros para enervar su posible buena fe, no hay necesidad de acudir a los tribunales para lograrlo; una medida semejante debería ser rechazada por falta de interés jurídico tutelable.

98. En suma, hay que tener cuidado de que las medidas de «reconocimiento» que se pidan al tribunal no supongan, a la postre, un subrepticio «ejercicio controlado jurisdiccionalmente» de derechos contractuales no discutidos ni inobservados por los contratantes, como también hay que cuidar que con tales medidas no se traspasen los límites subjetivos del acuerdo, que - como cualquier contrato- son del todo «relativos» y quedan circunscritos a las partes contratantes.

\section{La eficacia ejecutiva del acuerdo obtenido en mediación comercial transnacional: el «título ejecutivo» de la CSM}

99. La eficacia ejecutiva del acuerdo obtenido en mediación se contempla en el aptdo. 1 del art. 3 CSM, a cuyo tenor «cada Parte en la Convención ordenará la ejecución de los acuerdos de transacción de conformidad con sus normas procesales y en las condiciones establecidas en la presente Convención».

100. Esta eficacia ejecutiva está dada ex lege por el Convenio, aunque para que exista es un pre-requisito o presupuesto de ejecutividad que el acuerdo contenga la exigencia de una responsabilidad, procedente del incumplimiento de obligaciones, deberes o mandatos de conducta a las partes. De otra forma, faltará el presupuesto material de la ejecución forzosa, como instrumento de actuación de responsabilidad que es, enderezado a transformar la realidad para acomodarla a la situación jurídica dispuesta en el «título ejecutivo» ${ }^{84}$. Esta una cuestión importante, de un lado, porque -como ya se ha dicho y todavía se verá- convierte el propio documento privado por el que se instrumenta el acuerdo obtenido en mediación en el «título ejecutivo» que constituye el presupuesto de la ejecución («nulla executio sine titulo»); y, de otro lado, porque todavía es preciso examinar el contenido del título para purgar aquellas estipulaciones contractuales que deban quedar extra muros de la ejecución forzosa por no imponer al

\footnotetext{
${ }^{82}$ C. Esplugues Mota, “La convención de Singapur sobre Mediación y la creación de un título deslocalizado...”, loc. cit., p. 72.

${ }^{83}$ Así, C. Esplugues Mota, "La convención de Singapur sobre Mediación y la creación de un título deslocalizado...", loc. cit., p. 71; y, en referencia a la conciliación judicial, C. SENÉs MotILLA, Las disposiciones generales sobre la ejecución forzosa..., cit., p. 73.

${ }^{84} \mathrm{Vid}$., por todos, A. De la Oliva SANTos, “Conceptos fundamentales de la ejecución forzosa civil”, en La Ley, 1981, t. 4, pp. 930 y ss.; y, más recientemente, C. SENÉs Motilla, Las disposiciones generales sobre la ejecución forzosa ..., cit., pp. 27-29.
} 
contratante un mandato de conducta o no ser la conducta susceptible de imposición coercitiva, ya mediante actos de ejecución directa o sustitutiva de la conducta incumplida o ya mediante actos de ejecución indirecta consistentes en la compulsión personal sobre el deudor.

\section{A) La solicitud de medidas ejecutivas}

101. El carácter automático de la ejecutividad del acuerdo no significa que el proceso de ejecución se inicie de oficio. En el reino de la autonomía de la voluntad y del principio dispositivo, el proceso de ejecución se despacha o da comienza a instancia de parte, mediante una «solicitud de medidas» a la que aluden los aptdos. 1 y 5 del art. 4 CCSM. Esta referencia comprende, en España, tanto la «demanda ejecutiva» a la que se refiere el art. 549 LEC, como también -por identidad de razón- la solicitud de medidas cautelares ex art. 721 LEC, pues en ambos casos se acuerdan medidas consistentes en o dirigidas $a$ dotar de efectividad práctica al acuerdo obtenido en mediación a través de actos de naturaleza coactiva. Y puesto que de lo que se trata es de invocar el acuerdo obtenido en mediación y de pedir la adopción de medidas, resultan en este punto aplicables las prescripciones del art. 4 CSM sobre la documentación que la parte interesada debe presentar a las autoridades de ejecución, ya vistas [supra aptdo. III.2.A)], para pedir que se adopten las «medidas» ejecutivas.

102. Pero, ¿qué medidas debe adoptar el tribunal o la autoridad de ejecución? En principio, las que procedan, siempre que no contravengan el orden público español y la naturaleza dispositiva de la materia «transada», cuyo respeto ponen a salvo los motivos de denegación de la ejecución que el tribunal puede controlar de oficio al amparo de lo previsto en el aptdo. 2 del art. 5 CSM. Con estas precauciones, el tribunal o la autoridad de ejecución debe adoptar las «medidas» solicitadas, según el aptdo. 4 del art. 4 CSM, «con celeridad» o inmediatamente («expiditiously», dice la versión inglesa de la Convención). La CSM no concreta ninguna; el mandato de ejecución que se dirige a los Estados parte -como bien dice Esplugues Mota- «es genérico» ${ }^{85}$.

103. El art. 3.1 CSM se remite en bloque al sistema de ejecución forzosa de cada Estado al que acuda la parte para, «de conformidad con sus normas procesales y en las condiciones establecidas en la presente Convención», conseguir la efectividad del acuerdo ante el incumplimiento de la contraria, en escrupuloso respeto a la exclusividad de la soberanía territorial.

104. Con el proceso de ejecución el tribunal sustituye la actividad debida por la parte incumplidora, haciendo y obteniendo lo que ésta debió hacer voluntariamente, y esto no cambia por la circunstancia de que la actividad ejecutiva deba preordenarse - en este caso- a la obtención de un resultado perfecta o imperfectamente equivalente al cumplimiento de un acuerdo obtenido en mediación comercial internacional. Por este motivo, las medidas ejecutivas han de ser correlativas al contenido obligacional y material del acuerdo obtenido en mediación, en el sentido de que han de ser idóneas y proporcionadas para realizar coactivamente la obligación aceptada en el título, incluida la adopción -conforme a las previsiones de los arts. 699.II y passim LEC- de «apremios personales o multas pecuniarias». Lo que no cabe es desbordar ni los límites objetivos de los derechos y las obligaciones aceptadas por las partes, $\mathrm{ni}$-por elementales exigencias del derecho a la tutela judicial efectiva del art. 24.1 CE- el círculo de sujetos directamente concernidos en el acuerdo en su condición de contratantes.

\section{C) Los problemas de equivalencia del «título ejecutivo» de la Convención}

105. La CSM aspira a configurar un «título ejecutivo» que está integrado por el flamante «acuerdo obtenido en mediación comercial internacional» recogido en mero documento privado firmado por

${ }^{85}$ C. Esplugues Mota, "La convención de Singapur sobre Mediación y la creación de un título deslocalizado...”, loc. cit., p. 68. 
las partes y por el mediador o el centro de mediación [art. 4.4.a) CSM]. Mas el verdadero «título ejecutivo» que arroja la CSM es siempre complejo o formado por una pluralidad de actos documentados. Se advierte con claridad cuando, por no encontrarse el acuerdo firmado por el mediador, es preciso integrar el título con la suma del acuerdo y el documento o el certificado del mediador o del centro que acrediten que al acuerdo se llegó como resultado de una mediación objeto de la Convención de Singapur, y, en su defecto, con la aportación de cualquier otro elemento que el tribunal considere aceptable para probar este extremo [art. 4.4.b) CSM]. Pero incluso cuando el acuerdo incluye la firma del mediador, es necesario también integrar el «título ejecutivo» con aquellos que acrediten el incumplimiento de una o varias obligaciones asumidas en el acuerdo obtenido en mediación.

106. Dicho lo anterior, resulta problemático clasificar el acuerdo privado obtenido en mediación comercial internacional como título ejecutivo. ¿De origen y confección «judicial o asimilado» o de confección «no judicial»? De nuevo, nos vamos a encontrar con el problema de que un emergente documento de manufactura no judicial aspire a la máxima eficacia ejecutiva que nuestra legislación procesal reservó inicialmente a las sentencias y que ha ido progresivamente ampliando para abrazar otras decisiones y acuerdos, como laudos o resoluciones arbitrales y los acuerdos de mediación del art. 25 LMACM (art. 517.2.2. ${ }^{\circ}$ LEC). Sin embargo, el «juicio de equivalencia» que corresponde efectuar para subsumir este nuevo título ejecutivo en alguno de los ordinales tipificados en el art. 518 LEC, es arduo. Además, tampoco son convenientes los resultados que se siguen del régimen jurídico aplicable a su ejecución conforme a la LEC. Sistematizándolas, las dificultades se concentran en dos frentes.

107. El primer problema radica en que ninguno de nuestros títulos ejecutivos nacionales consiste en un mero documento privado o en un escrito -o varios, tanto da-desprovisto de las más mínimas y elementales garantías de fiabilidad. A estos documentos privados - como ya se vio- se les endereza en España hacia procedimientos especiales para ganar en ellos -a través del juicio cambiario o del procedimiento monitorio- la eficacia ejecutiva, con la limitación de que han de documentar la exigencia de obligaciones dinerarias, no condicionadas ni ilíquidas, porque son cauces de tutela del crédito que solo permitirán fundar un proceso de ejecución dineraria. De otra manera, solo será posible obtener la eficacia ejecutiva mediante la homologación del acuerdo por la vía judicial, puesto que la vía notarial también exige el cumplimiento de los consabidos requisitos del art. 520 LEC, con los mismos efectos de reducir el radio de acción de la tutela ejecutiva. Estas dificultades no ocultan que el problema, en el fondo, radica en que la CSM ha acogido un «título ejecutivo» que es ajeno a la calidad que la LEC exige para dispensar la tutela ejecutiva, como lo muestra -ya lo hemos visto supra aptdo. II.2- que la misma idea de atribuir eficacia ejecutiva directa al acuerdo de mediación de carácter interno ya fue rechazada en nuestro país al poco de echar a andar el Anteproyecto de reforma de la LMACM de febrero de 2010, que se proponía instaurarla.

108. El carácter omnicomprensivo de las medidas ejecutivas que deben dispensarse ex arts. 3 y 4 CSM abonaría que - una vez más- se acuda a la «ficción» consistente en atribuir en España la consideración de «título ejecutivo judicial o asimilado» a este «acuerdo privado obtenido en mediación comercial internacional», sin la menor garantía de autenticidad, fehaciencia y control de legalidad en su formación. Esta artificiosa asimilación es el «precio» de permitir que el incumplimiento del acuerdo pueda fundar tanto una ejecución de tipo dinerario (regulada en los arts. 571 y ss. LEC), cuanto una ejecución de tipo no dinerario (arts. 699 y ss. LEC). Ahora bien, esta «ficción» también conlleva desventajas. Una no menor es resolver si ha de aplicársele el plazo de caducidad ejecutiva por el transcurso del plazo de cinco años del art. 518 LEC, de la que no hay razón para dispensar a estos acuerdos, como tampoco se hace con los transfronterizos europeos ${ }^{86}$. Pero, con todo, la mayor desventaja está situada en la estrechez legal de los motivos de oposición a la ejecución por razones de fondo que la LEC permite oponer al ejecutado cuando la ejecución está fundada en un título ejecutivo judicial o asimilado. Este segundo frente de dificultades merece alguna atención.

${ }^{86}$ Así, entre otros, C. SEnÉs Motilla, Las disposiciones generales sobre la ejecución forzosa ..., cit., p. 55. 


\section{D) El ámbito de cognición en el seno del proceso de ejecución español}

109. Las dificultades de encaje del nuevo título ejecutivo de la CSM en el sistema de ejecución de la LEC se concentran en la estrechez de los motivos que la LEC permite alegar al ejecutado para oponerse a la ejecución en su conjunto. Aun cuando en España aceptáramos el acuerdo en cuestión con el valor de «título ejecutivo», el mayor inconveniente sigue estando en que los motivos de denegación de la eficacia ejecutiva que regula el art. 5 CSM son demasiado amplios para las limitaciones de la oposición a la ejecución tanto de títulos ejecutivos judiciales o asimilados (vid. art. 556.1 LEC), cuanto de los extrajudiciales (vid. art. 557 y 558 LEC), dado que ninguno de ellos - con la salvedad del control de cláusulas abusivas en contratos de consumo, que no hace al caso- permite entrar al conocimiento de la validez o la eficacia del negocio jurídico subyacente al título.

110. Quiere decirse que, dada la amplitud de los motivos de denegación del art. 5 CSM que seguidamente se expondrán, no hay que temer, por ahora, que a los acuerdos obtenidos en una mediación transnacional pueda terminar pasándoles lo que a los laudos arbitrales españoles en apenas quince años, esto es: que, con la Ley de Arbitraje de 1988 y la LEC de 1881, la protocolización y la notificación del laudo eran requisitos que condicionaban su ejecutividad y que, después, fueron atenuados por la LEC de 2000 y la Ley de Arbitraje de 2003, para prescindir por completo de la protocolización del laudo (a cambio de que el ejecutado pueda oponerse a la ejecución alegando la falta de autenticidad del laudo ex art. 559.1.4. ${ }^{\circ}$ LEC), quedando únicamente la exigencia de aportar el laudo, como título ejecutivo (art. 517.2.2. ${ }^{\circ}$ LEC), y el convenio arbitral y los documentos acreditativos de la notificación de aquél a las partes (art. 550.1.1 $1^{\circ}$.II LEC), como documentación complementaria necesaria, de carácter subsanable (cfr. art. 559.1.3. ${ }^{\circ}$ y .559.2 LEC).

111. El ámbito de contradicción que el art. 5 CSM permite suscitar en la ejecución del acuerdo que diseña la Convención no es compatible con los estrechos límites de cognición judicial que permite el proceso de ejecución español y que - hay que añadir- conviene que no se desnaturalicen para evitar que la ejecución se convierta en un proceso de cognición abreviado. Desde aquí sugiero que, tal vez, convenga empezar a estudiar, desde el Derecho procesal, si -de adherirse la UE o España a la CSMsería conveniente introducir un cauce específico basado en técnica monitoria, que permita adoptar de plano medidas cautelares y anticipatorias, en cuyo seno - como muestra el juicio cambiario- se pueda acomodar un incidente contradictorio para examinar las tasadas causas de denegación del art. 5 CSM, antes de franquear en definitiva la puerta del despacho de la ejecución.

\section{Los motivos de denegación del art. 5 CSM}

112. El art. 5 CSM contiene el régimen jurídico de los motivos que, con el carácter de tasado y exhaustivos, pueden impedir el "reconocimiento" o la ejecución del acuerdo, unos, apreciables de oficio, y todos, alegables a instancia de parte como defensas, excepciones o motivos de oposición frente a, en definitiva, cualquier intento de hacer valer el acuerdo obtenido en mediación comercial internacional.

113. Los motivos de denegación del art. $5 \mathrm{CSM}$-objeto de las reuniones del $67^{\circ}$ período de sesiones del Grupo de Trabajo- constituyen un numerus clausus que tienen por consecuencia impedir, de entrada, que el tribunal se resista al "reconocimiento" o a la ejecución por causas no subsumibles en cualquiera de las diez circunstancias que se allí recogen ${ }^{87}$, como, p. ej., para, separándose de las disposiciones establecidas en el art. $4 \mathrm{CSM}$, pedir al solicitante que aporte instrumento público ejecutivo conforme a la ley nacional, es decir, en España, el acuerdo en escritura pública que cumpla los requisitos del art. 520 LEC o que se otorgue en la específica del art. 25 LMACM.

\footnotetext{
87 Vid. T. Schnabel, "The Singapore Convention on Mediation: A Framework...", loc. cit. p. 42; y C. Esplugues Mota, "La convención de Singapur sobre Mediación y la creación de un título deslocalizado...”, loc. cit., p. 72.
} 
114. La lista de motivos no es extensa y corre paralela, deliberadamente ${ }^{88}$, a los motivos de oposición del laudo del art. V CNY hasta el punto de que, como éste, el art. 5 CSM divide los motivos en razón del tratamiento procesal que cabe suscitar: (i) de oficio (aptdo. 2 CSM) y (ii) instancia de parte (aptdo. 1). Por este orden los abordamos.

\section{A) Causas de denegación que fundan el control de oficio por el tribunal}

115. El aptdo. 2 del art. 5 CSM confiere al tribunal o la autoridad a la que se pidan actos de reconocimiento o ejecución del acuerdo obtenido en mediación, la potestad de «negarse a otorgarlas si considera que: a) El otorgamiento de las medidas solicitadas sería contrario al orden público de esa Parte; o b) El objeto de la controversia no es susceptible de resolverse por la vía de la mediación con arreglo a la ley de esa Parte». Aunque no lo diga el art. 5 CSM, nada impide que estos motivos de control de oficio se susciten también a instancia de parte, por el elemental criterio de «quien puede lo más puede lo menos».

116. La contrariedad del orden público del Estado del foro no va referida - no es posible, como hemos visto- al ordenamiento de ningún «Estado de origen», sino a aquel al que acuda el contratante interesado en obtener el reconocimiento o la ejecución. En España, esto supone salvaguardar los principios y valores esenciales que inspiran nuestro ordenamiento, como, p. ej., la protección del patrimonio artístico y medioambiental, la libre circulación de mercancías, la protección de la propiedad intelectual o la libre competencia ${ }^{89}$. Ahora bien, con lo que ha de confrontarse el orden público español no es con el contenido mismo del acuerdo obtenido en mediación, cuanto con «el otorgamiento de medidas», como indica expresamente el art. 5.2.a) CSM. Esto supone que la CSM ha restringido el ámbito de actuación del orden público para que opere en la forma «atenuada» que se asocia a los actos e instrumentos de preexistente validez ${ }^{90}$. En el marco de la CSM, el control de orden público opera oblicuamente, en el sentido de que: (i) el tribunal no puede entrar a fiscalizar el contenido del acuerdo sino solo en cuanto resulte necesario para acordar medidas de ejecución; y (ii) son estas medidas de ejecución -su otorgamiento, dice el texto- las que hay que pasar por el filtro del control del orden público español. O dicho de otra manera: el control de oficio basado en el orden público tiende a no dar efectos en España a aquellas medidas de ejecución que inflijan un daño a los valores y principios básicos españoles, como, p. ej., en materia de «seguridad nacional», citada como referencia en el seno de la comisión negociadora ${ }^{11}$. La configuración elegida preserva, así, la validez y existencia del acuerdo mismo, que podrá seguir circulando extraterritorialmente pese a que resulten denegadas las medidas de ejecución por contrariedad con el orden público, sin perjuicio de que a instancia de parte se suscite la invalidez o ineficacia del acuerdo en sí.

117. En segundo lugar, también puede - y debe- el tribunal examinar de oficio, al amparo del art. 5.2.b) CSM, que «el objeto de la controversia no es susceptible de resolverse por la vía de la mediación con arreglo a la ley de esa Parte». Esta disposición sitúa en el foco de atención no en la controversia actual que haya motivado el recurso a la ejecución, sino la controversia subyacente y previa al acuerdo obtenido en mediación que este pacificó indebidamente, en contra de la naturaleza indisponible o de las limitaciones puestas a la mediación en el Estado del foro. Tal es el caso de materias que la ley

\footnotetext{
${ }^{88}$ T. Schnabel, "The Singapore Convention on Mediation: A Framework...", loc. cit. p. 42.

${ }^{99}$ Así, A. L. Calvo Caravaca, A. L. y J. Carrascosa González, Derecho internacional Privado, cit., pp. 612-613.

90 Vid., por todos, A. L. Calvo Caravaca, A. L., y J. Carrascosa González, Derecho internacional Privado, cit., p. 617.

${ }_{91}$ T. SCHNABEL, "The Singapore Convention on Mediation: A Framework...", loc. cit., p. 54. Hago notar que en el seno de la comisión negociadora ya se puso de manifiesto que la salvaguarda del orden público del Estado del foro podría convertirse en la puerta por la que pudieran entrar las exigencias, formalidades y garantías de las legislaciones nacionales que fueran en contra de la libertad de condiciones que la Convención presupone a la mediación, como, p. ej., los requisitos de formación o de capacitación profesional del mediador.
} 
nacional obliga a determinar judicialmente o por medio de una autoridad pública de forma necesaria, lo que, en el ámbito comercial internacional, son casos infrecuentes o $\operatorname{raros}^{92}$.

118. El momento adecuado para que, en España, tenga lugar este control de oficio es, en principio, el de despacho y autorización de la ejecución, regulado en los arts. 551-552 LEC. En este punto, cabe señalar que el carácter exclusivo de los motivos de oposición del art. 5 CSM no debe impedir que el tribunal efectúe el normal examen de los presupuestos procesales y materiales que determinan el despacho de la ejecución (art. 551.1 LEC), siempre que sean compatibles con las condiciones puestas por el propio CSM.

119. Esto quiere decir que un tribunal español al que se le soliciten medidas de ejecución o cumplimiento de un acuerdo objeto de la CSM, deberá verificar: (i) la concurrencia de los presupuestos y requisitos procesales, tales como la competencia del tribunal, la postulación de las partes, el pago de la tasa judicial, etc.; (ii) la «regularidad formal del título», que se proyecta, primero, sobre la comprobación de que el documento privado del acuerdo de mediación cae en el ámbito de aplicación de la CSM, segundo, sobre las exigencias documentales que pone el art. 4 CSM y, tercero, con la necesidad de aportar aquella otra que acredite también la existencia de un incumplimiento por parte del ejecutado del que deriva la responsabilidad que se trata de depurar en la ejecución, como quedó dicho; y (iii) que los actos de ejecución solicitados sean conformes con la naturaleza y el contenido del «título ejecutivo», que es un presupuesto referido a la relación de idoneidad y correlación entre la obligación jurídico-material incumplida y los concretos actos de tutela que se piden al tribunal, cuestión que no debemos confundir con el motivo de oposición de fondo que cabe suscitar a instancia de parte al abrigo de la letra d) del art. 5.1 CSM («el otorgamiento de medidas sería contrario a los términos del acuerdo»), que pertenece al terreno de la interpretación del contrato que no corresponde adelantar ahora. Pues bien, en este trance del despacho de la ejecución es cuando deberá el tribunal extender, de oficio, su examen a la eventual contrariedad del orden público y al carácter dispositivo de la controversia antecedente que las partes dirimieron mediante mediación.

\section{E) Causas de denegación alegables a instancia de parte}

120. El aptdo. 1 del art. CSM, por su parte, relaciona los motivos de oposición o defensas que puede la contraparte alegar para impedir que se adopten o conseguir que se extingan las medidas de reconocimiento o de ejecución basadas en el acuerdo obtenido en mediación objeto de la Convención. El empleo de los tiempos verbales presentes y futuros con que arranca el art. 5 CSM [«la autoridad competente (...) en que se soliciten medidas de conformidad con el artículo 4 podrá negarse a otorgarlas a instancia de la parte contra la cual se solicitan, solo si esa parte suministra (...)]», puede ser tomado como un indicio cualificado de que el texto de Singapur desea que el contradictorio tenga lugar, siempre que sea posible, antes de acordar las medidas; pero no hay que excluir la lectura contraria, como sucederá, p. ej., si se acuerdan medidas cautelares inaudita parte o, en general, si en España reconducimos la ejecución del acuerdo obtenido en mediación al proceso de ejecución; supuesto en el que siempre corresponde despachar la ejecución inaudita parte (art. 551.1 LEC) y sin recurso alguno (art. 551.4 LEC), quedando condicionada la contradicción al hecho posterior de que el ejecutado suscite, por escrito, la «oposición a la ejecución» dentro de los diez días siguientes a la notificación del auto de despacho (art. 556.1 LEC).

121. En definitiva, el art. 5 CSM habilita los motivos de oposición, excepciones o defensas que puede alegar la contraparte frente a la que, de una u otra forma, su co-contratante haga valer el acuerdo obtenido en mediación, p. ej., cuando se alegue la «cosa transada» en el curso de un proceso declarativo, o se pidan diligencias preliminares o la adopción de medidas cautelares, o - en fin- para oponerse a la ejecución en su conjunto o a concretos actos ejecutivos a los que puedan alcanzar los motivos del art. 5

${ }^{92}$ Vid. T. SCHNABel, “The Singapore Convention on Mediation: A Framework...”, loc. cit., pp. 54-55. 
CSM. Huelga decir que sobre la parte frente a la que se pidan las medidas pesa la carga de alegar y de probar las circunstancias de cada motivo.

122. Siguiendo el orden en que se recogen los motivos de oposición en el art. 5 CSM, hallamos, en primer lugar, la alegación consistente en que «Una de las partes en el acuerdo de transacción tenía algún tipo de incapacidad». Este motivo es el homólogo del art. V.1.a) CNY, con la diferencia de que la CSM no contiene norma de conflicto que determine la ley aplicable a la capacidad. La razón -según cuenta el representante norteamericano ${ }^{93}$ - es que a la comisión negociadora de la CSM les pareció inútil e irrelevante indicarlo, porque en la mayor parte de los acuerdos comerciales internacionales obtenidos en mediación intervienen uno o más abogados en la negociación, lo que dificultad la concurrencia de este motivo (que, a mayores, es de interpretación restrictiva). Esplugues Mota apunta, además, que a falta de un ordenamiento jurídico de referencia, «la incapacidad se entiende en términos absolutos, sin venir reputado de ley alguna que permita determinarlo $\rangle^{94}$. Hay que señalar que toda posible influencia indebida del mediador en la formación de la voluntad de alguno de los contratantes es reconducible a la letra e) del art. 5.1 CSM.

123. En segundo lugar, bajo la letra b) del art. 5.1 CSM se agrupan varios submotivos que permiten cuestionar la validez o la eficacia del acuerdo obtenido en mediación, en sí mismo considerado. Esta relación de submotivos está encabezada por la alegación de ser el acuerdo «nulo, ineficaz o no puede cumplirse con arreglo a la ley a la que las partes lo hayan sometido válidamente o, si esta no se indicara en él, a la ley que considere aplicable la autoridad competente de la Parte en la Convención en que se soliciten medidas de conformidad con el artículo 4» [art. 5.1.b) i) CSM]. Al amparo de este motivo el ejecutado puede cuestionar la validez, la eficacia y también la imposibilidad de cumplimiento del acuerdo mismo resultante de la mediación, que ha de medirse con el metro que proporciona la norma de conflicto que -aquí sí- expresamente apunta, en primer lugar, a la ley a la que las partes hayan acordado someterlo válidamente $\mathrm{o}$, en su defecto, al que repute aplicable el tribunal del foro según su sistema de Derecho internacional privado. La inclusión expresa de la imposibilidad de cumplimiento como causa de oposición a la ejecución del contrato, vadea la cuestión - sustantiva- acerca de si esta circunstancia determina la suspensión del contrato o su extinción, pues, a los efectos de recabar la tutela de los tribunales, la CSM iguala ambos supuestos al quedar establecido que, si el ejecutado lo alega y lo prueba, producirá el efecto de denegar o revocar los actos de tutela que se hayan dispensado. Adviértase, por lo demás, que -en la lógica de la CSM- la falta de firma del contrato por las partes conviene en inaplicable la CSM, lo que puede ser alegado como un prius para impedir que se dispense una tutela ejecutiva ilícita o despachada sin título ejecutivo; la LEC permite alegarlo ampliamente al amparo del motivo procesal del ordinal $3 .^{\circ}$ del art. 559.1 LEC.

124. También afecta al acuerdo mediado en su conjunto el submotivo de oposición que permite alegar que este «no es vinculante, o no es definitivo, según lo estipulado en el propio acuerdo» [art. 5.1.b) ii) CSM]. Esta disposición toma como marco autorrefencial el propio acuerdo y puede perfectamente aplicarse a aquellos contratos que albergan cláusulas condicionales o articuladas eventualmente, a modo de protocolo de cumplimiento, que van desencadenando su eficacia obligatoria secuencialmente. Lo más normal es que esta alegación se use para poner de manifiesto que no se ha aportado el acuerdo final, sino una versión previa; o que el documento aportado como título no es más que una proposición de acuerdo. En todo caso, la falta de exigibilidad de la conducta debida o la improcedencia de acordar la medida ejecutiva pedida debe deducirse de los propios términos del acuerdo («within the four corners of the mediated settlement», en palabras de SCHNABEL ${ }^{95}$ ).

125. Y todavía referido al contrato resultante de la mediación, es posible alegar que el acuerdo obtenido en mediación en el que se han fundado o se pretenden fundar medidas de tutela, «fue modificado

\footnotetext{
${ }^{93}$ T. SCHNABEL, "The Singapore Convention on Mediation: A Framework...", loc. cit., pp. 43-44.

${ }^{94}$ C. Esplugues Mota, "La convención de Singapur sobre Mediación y la creación de un título deslocalizado...”, loc. cit., p. 73.

${ }_{95}$ T. Schnabel, "The Singapore Convention on Mediation: A Framework...", loc. cit., p. 46.
} 
posteriormente» [art. 5.1.b) iii) CSM]. Adviértase que en esta modificabilidad de la «cosa transada» se pone de manifiesto - una vez más- las diferencias que separan la construcción de esta noción, basada en el principio de libertad de la contratación, de la «cosa juzgada material», basada en el de la seguridad jurídica; evidencia, en suma, un carácter obligacional que, en consecuencia, puede ser novado por la misma vía negocial. No es preciso que la modificación sea el resultado del mismo o de otro procedimiento de mediación; tampoco es necesario que la modificación afecte a todo, a gran parte o a la mayor parte del contenido obligacional del contrato. Basta con que la modificación sea susceptible de afectar cualitativa o cuantitativamente a los actos de ejecución solicitados o acordados, para que deba prosperar este motivo.

126. Bajo la letra c) del art. 5 CSM se agrupan un par de submotivos que ponen el foco no ya en el contrato conjuntamente considerado, sino en «las obligaciones estipuladas en el acuerdo de transacción»; que consisten en poder alegar que «se han cumplido» [art. 5.1.c) i) CSM] o que «no son claras o comprensibles» [art. 5.1.c) ii) CSM]. Mediante el primer motivo es posible alegar -con la carga de probar- el cumplimiento de la obligación de cuya efectividad se trata. En esto punto, hay que observar que puede representar un problema las exigencias documentales que los arts. 556.1 y 557.1.1. ${ }^{\mathrm{a}}$ LEC piden para poder alegar con éxito -en España- el pago, tanto en la ejecución de títulos judiciales como en la de los extrajudiciales. Del segundo motivo - que obedece a la iniciativa alemana durante las negociaciones de la Convención- vale decir que al tribunal no le está dado aclarar ni integrar oscuridades y omisiones de un instrumento puramente convencional al que debe permanecer ajeno. El tribunal al que se acuda para hacer valer el acuerdo no tiene más potestad que la de acordar $-\mathrm{o}$ no- los actos que resulten precisos para dotarlo de efectividad. Si esto no pudiera hacerlo el tribunal a causa de la falta de precisión o de oscuridades del contrato, la CSM implícitamente opta por preferir una falta de efectividad del acuerdo antes que su heterointegración por parte del tribunal del foro (al que -dicho sea de pasonada impide promocionar un intento de autointegración del acuerdo convocando a las partes a una comparecencia). Con todo, la configuración de este motivo se compadece mal con que solo pueda ser opuesto a instancia de parte, cuando, por la entidad de los defectos descritos («so confusing or ill-defined»), debería poder apreciarlo el tribunal de oficio, como el propio ScHNABEL sugiere sin llegar a admitirlo ${ }^{96}$.

127. La letra d) del art. 5.1 CSM ha innovado un motivo de oposición que resulta desconocido en el contexto del CNY y que en el CSM tiene por fundamento preservar la voluntad de las partes expresada en el contrato y evitar que pueda ser desnaturalizada a través de los actos de "reconocimiento" o de ejecución dispensados por el tribunal. En concreto, el motivo de oposición consiste en alegar que «el otorgamiento de medidas sería contrario a los términos del acuerdo de transacción». Ésta -si bien se mira- es la "faceta sustantiva", porque penetra en el terreno de la interpretación del contrato, de la "faceta procesal" que recoge el art. 5.2.b) CSM - ya vista supra- sobre la idoneidad que debe discurrir entre la obligación incumplida y los actos de tutela que se piden al tribunal. Mientras que el motivo del art. 5.2.b) CSM solo permite someter a examen la adecuación o vínculo de medio a fin entre el contrato y la tutela impetrada, con este otro motivo que ahora nos ocupa se trata de que el tribunal cuide que, aun siendo idóneos los actos en cuestión, no se desfigure el interés jurídico-económico del contrato, ni se tergiverse su contenido.

128. Los dos últimos motivos de las letras e) y f) del art. 5.1 CSM cierran la relación de motivos de oposición alegables a instancia de parte. Se trata de dos motivos -introducidos por la iniciativa israelí, como fórmula de compromiso- que permiten denunciar, a instancia de parte, ilicitudes ocurridas en el procedimiento de mediación o concernientes a la conducta del mediador. Aunque el propósito inicial de la comisión negociadora era convenir un texto puro de reconocimiento y ejecución que no contuviera ninguna regla de estándar mínimo de calidad de la mediación con el fin de fomentar la acogida del tratado por el mayor número de Estados, no ha sido posible orillar por completo ciertas garantías mínimas que han cristalizado en estas letras e) y f) del art. 5.1 CSM. Su función, por tanto, no radica en imponer -en positivo- reglas de calidad de la mediación que -en el imaginario del Grupo de Trabajo II- pu-

${ }^{96}$ T. SchnABEL, "The Singapore Convention on Mediation: A Framework...”, loc. cit., p. 48. 
dieran terminar "encorsetando" la mediación y frenando su difusión, sino - desde otro prisma- depurar indirectamente las ilicitudes más graves a través de cercenar la eficacia extraterritorial de aquellos acuerdos resultantes de procedimientos de mediación viciados. En todo caso, si examinamos los casos que llegan a los tribunales sobre estas cuestiones, veremos que es muy infrecuente que los tribunales declaren la inejecutabilidad de los acuerdos por estos motivos $^{97}$.

129. Así, la letra e) del art 5.1 CSM permite alegar como motivo de oposición frente a las medidas de efectividad del acuerdo, el hecho de que «el mediador incurrió en un incumplimiento grave de las normas aplicables al mediador o a la mediación, sin el cual esa parte no habría concertado el acuerdo de transacción». De este motivo de oposición llaman la atención tres extremos. El primero es que, a su amparo -como se aprecia- no es posible exigir al procedimiento de mediación ni al mediador ningún estándar legal predeterminado solo por ser aplicables en virtud de las leyes nacionales de mediación o de estar comúnmente aceptadas, tales como la cualidad de la independencia o la neutralidad del mediador, o una determinada formación, o la confidencialidad, o dispensar un trato justo y equitativo con las partes. Para la $\mathrm{CSM}^{98}$ solo importan las condiciones que las partes quisieron que fueran aplicables a su mediación, bien relativas al procedimiento de mediación, o bien a la persona del mediador, quien, así, bien podría, p. ej., no ser neutral si las partes lo han decidido en función de sus legítimos intereses; o carecer de estudios reglados, si no se resultan necesarios para entender y favorecer el acuerdo en la materia de que se trate. En segundo lugar, debe haberse producido un «incumplimiento grave», y no cualquier apartamiento de las normas aplicables por la voluntad de las partes, lo que nos sitúa ante un concepto jurídico indeterminado que será objeto de las más diversas interpretaciones en el futuro. Y en tercer lugar y conectado con esto último, la CSM emplea para medir la gravedad de la infracción el hecho de que el incumplimiento esté enderezado a influenciar indebidamente la voluntad de la parte a aceptar el acuerdo resultante del proceso de mediación, esto es, tiene que ser decisivo para obtener la formación de la voluntad y no deseado por la parte influenciada. En suma, este motivo está redactado de forma tan sumamente restrictiva que cuesta imaginar supuestos que queden dentro de las fronteras del Derecho privado, sin deslizarse hacia las procelosas aguas del Derecho penal.

130. Por su parte, la letra f) del art. 5.1 CSM aborda, específicamente, la conducta ilícita del mediador consistente no haber «revel[ado] a las partes circunstancias que habrian suscitado dudas fundadas acerca de la imparcialidad o independencia del mediador y el hecho de no haberlas revelado repercutió de manera sustancial o ejerció una influencia indebida en una de las partes, la cual no habría concertado el acuerdo de transacción si el mediador las hubiera revelado». Esta es una exigencia muy común en el mundo del arbitraje que la CSM ha querido importar a la mediación para dotar a la figura del mediador de las mínimas garantías de imparcialidad y de independencia que las partes estén dispuestas a aceptar. La imparcialidad y la independencia a la que se refiere la CSM en este motivo no se miden -deliberadamente- en términos de apariencia, como se hace con la de jueces, magistrados y árbitros en razón de sus potestades para dirimir el conflicto heterodeterminándolo, sino que va más allá. Este motivo de oposición exige, de un lado, «dudas fundadas» sobre la imparcialidad y la independencia del mediador, es decir, que estén objetivamente justificadas, y no basada en conjeturas o suposiciones; y, de otro lado, la falta de revelación de las circunstancias generadoras de un posible conflicto de interés en el mediador tiene que ser determinante de la conclusión del acuerdo, en el sentido de que, de haberse conocido aquellas circunstancias, la parte no lo habría concluido. Los términos de este motivo de oposición son, como en el caso anterior, muy estrictos, incluso a los ojos de juristas provenientes de ordenamientos funcionales, por la exigencia de «una relación de causalidad entre la revelación y el acuerdo concluido por las partes» (EsPluges MotA ${ }^{99}$ ), que no cabe acreditar mediante prueba directa, por el carácter «diá-

\footnotetext{
97 Vid., por todos, D. QUEK ANDERSON, "Litigating over mediation-how should the courts enforce mediated settlement agreements?", en Singapore Journal of Legal Studies [2015], pp. 105-134.

${ }_{98}$ T. Schnabel, "The Singapore Convention on Mediation: A Framework...", loc. cit., pp. 49-54.

99 C. Esplugues MотA, "La convención de Singapur sobre Mediación y la creación de un título deslocalizado...", loc. cit., p. 76; en el mismo sentido, T. Schnabel, “The Singapore Convention on Mediation: A Framework...", loc. cit., p. 53.
} 
bolico» de probar hechos negativos (= lo que no sucedió, aunque pudo haber sucedido). En este punto, hago notar que es lícito acudir a la llamada prueba por indicios, acumulando todos aquellos elementos probatorios sobre hechos periféricos de los que quepa inferir racionalmente la probable existencia del hecho presunto, como los que muestren la importancia que para la parte tenía el grado de implicación del mediador en la defensa, p. ej., de la protección de datos.

131. Examinados los motivos de oposición, fácilmente se aprecia la dificultad de encajarlos en los también cerrados motivos de oposición a la ejecución por razones de fondo que regulan el art. 556.1 LEC -para los títulos ejecutivos judiciales y asimilados - y los arts. 557 y 558 LEC - para los extrajudiciales-. Alguno de ellos, como, p. ej., el pago o cumplimiento, la pluspetición, la prescripción o la quita se pueden usufructuar, a condición de no aplicar las limitaciones probatorias que la LEC impone para su acreditación. Pero el gran problema radica -como quedó indicado supra, aptdo. IV.2.C- en que hay motivos de oposición en el art. 5 CSM que no tienen homólogo en la LEC, como, paradigmáticamente, el que permite suscitar los problemas de validez, eficacia y exigibilidad del acuerdo mismo obtenido en mediación.

\section{Las «reclamaciones paralelas» en el marco de la CSM}

132. Dentro de la simplicidad que se ha propuesto diseñar la CSM para implantar la circulación y la inmediata ejecutividad de acuerdos obtenidos en mediación, no se ha olvidado la CSM de prever los problemas que pueden surgir en el curso de un proceso de ejecución del acuerdo a causa de «reclamaciones paralelas»; esto es, de aquellos segundos procesos que, por la causa que sea (=litispendencia o cone$x i d a d$ ), pueden interferir en las medidas ya adoptadas por un primer tribunal. Hay que decirlo sin rodeos así, porque la farragosa redacción del art. 6 CSM en su versión en español no facilita su comprensión tras una primera lectura (a diferencia de la versión inglesa); este artículo dice así: «Si se presenta ante un órgano judicial, un tribunal arbitral o cualquier otra autoridad competente una solicitud o reclamación relativa a un acuerdo de transacción que pueda afectar a las medidas solicitadas de conformidad con el artículo 4, la autoridad competente de la Parte en la Convención en que se soliciten esas medidas podrá, si lo considera procedente, aplazar la decisión y también podrá, a instancia de una de las partes, ordenar a la otra que otorgue garantías apropiadas».

133. Esto significa - dicho en romano paladín- que el tribunal del segundo proceso al que se pida la adopción de medidas que puedan interferir en las previamente ya adoptadas por otro, puede, en ejercicio una facultad que el art. 6 CSM le confiere con carácter discrecional («si lo considera procedente»), suspender el procedimiento o, si lo pide la parte afectada, condicionar la concesión o el mantenimiento de las medidas a que el solicitante preste garantías suficientes en la forma y cuantía que el tribunal determine. Estas «garantías apropiadas» tienen por finalidad asegurar el eventual y futuro resarcimiento al afectado en razón de una sobreejecución o de una doble ejecución del mismo acuerdo obtenido en mediación.

\section{Epílogo}

134. Finalizo con una frase leída al vuelo -también ella «deslocalizada»-que dice que el éxito o el fracaso de una Convención se mide por las adhesiones que genera y no por las expectativas que levanta. Esto - creo- es aplicable a la Convención de Singapur de 2019 que echa a andar en estos días y que, en función de las adhesiones que consiga concitar, puede terminar abriendo una brecha importante en el régimen de circulación de los contratos comerciales internacionales.

135. Desde el punto de vista unieuropeo y español, el título ejecutivo que propone la CSM para fomentar la mediación no reviste las «condiciones de calidad» que en España y en la mayor parte de los países europeos condicionan el acceso a la tutela ejecutiva. La CSM, en su propósito de fomentar la 
mediación a través de la atribución de fuerza ejecutiva automática, ha ido mucho más allá y se ha dejado por el camino las garantías de autenticidad, fehaciencia y legalidad, que son las condiciones a la que se ata la ejecutividad de instrumentos confeccionados al margen del proceso, por no mencionar que ha prescindido por completo de todo marco legal de referencia como el Estado de origen o Estado de la sede del acuerdo obtenido en mediación y, con ello, ha desaparecido el presupuesto de la «ejecutividad en origen» del título, que se reputa un estorbo, una formalidad inútil que frena la circulación del acuerdo.

136. A mi humilde parecer, la CSM no ha calibrado la calidad del título con la eficacia procesal que es capaz de desatar. El fomento de la mediación comercial internacional a través de la introducción de un régimen radical de inmediata efectividad extraterritorial del acuerdo, exige ofrecer certidumbres a todos los agentes del mercado, incluidos los Estados en cuyas manos queda el uso de la vis ejecutiva de la que depende, en última instancia y llegado el momento patológico del incumplimiento, la plena efectividad del acuerdo objeto de la CSM. Pero no existe certidumbre cuando se opta por prescindir de garantías elevando un simple documento privado a la categoría de título ejecutivo por el solo hecho de que haya intervenido un mediador o un centro de mediación asistiendo a las partes a resolver sus diferencias en el plano comercial internacional, en claro contraste con todas las garantías y condiciones que se exigen a las resoluciones judiciales provenientes de los sistemas nacionales de justicia, que quedan devaluados frente al modelo deslocalizado de «justicia convencional» que diseña la CSM.

137. Hasta donde alcanzo a entender, aun cuando -por la vía de las reservas del art. 8- la firma de esta Convención pusiera a salvo la aplicación preferente de la normativa UE sobre reconocimiento y ejecución de decisiones en materia civil y mercantil en el espacio judicial europeo, el sistema que propone la CSM conduce a un resultado - a mi parecer- difícilmente aceptable en términos de política-legislativa, a saber: que resulte más fácil la ejecución de un acuerdo de mediación firmado "en" o "desde" o "hacia" o "relativo a" inversiones en Arabia Saudí o en Fiji, que la de uno proveniente de Francia o de Países Bajos. Esto -y no otra cosa- es, hoy, lo que ofrece la CSM. También es verdad que ni España ni la UE se pueden apear del probable futuro del comercio internacional para el que está pensado el texto de Singapur. 